\title{
Hydroclimate of the Andes Part II: Hydroclimate Variability and Sub-Continental Patterns
}

\author{
Paola A. Arias ${ }^{1 *}$, René Garreaud ${ }^{2}$, Germán Poveda ${ }^{3}$, Jhan Carlo Espinoza ${ }^{4}$, \\ Jorge Molina-Carpio ${ }^{5}$, Mariano Masiokas ${ }^{6}$, Maximiliano Viale $^{6}$, Lucia Scaff ${ }^{7}$ and \\ Peter J. van Oevelen ${ }^{8}$
}

${ }^{1}$ Grupo de Ingeniería y Gestión Ambiental (GIGA), Escuela Ambiental, Facultad de Ingeniería, Universidad de Antioquia, Medellín, Colombia, ${ }^{2}$ Department of Geophysics, Universidad de Chile, Santiago, Chile, ${ }^{3}$ Department of Geosciences and Environment, Universidad Nacional de Colombia, Medellin, Colombia, ${ }^{4}$ Université Grenoble Alpes, IRD, CNRS, G-INP, IGE (UMR 5001), Grenoble, France, ${ }^{5}$ Instituto de Hidráulica e Hidrología (IHH), Universidad Mayor de San Andrés, La Paz, Bolivia, ${ }^{6}$ Instituto Argentino de Nivología, Glaciología y Ciencias Ambientales (IANIGLA), CCT CONICET, Mendoza, Argentina, ${ }^{7}$ Global Water Futures, CFREF, University of Saskatchewan, Saskatoon, SK, Canada, ${ }^{8}$ International GEWEX Project Office, George Mason University, Fairfax, VA, United States

OPEN ACCESS

Edited by:

David Glenn Chandler, Syracuse University, United States

Reviewed by: Mario Cordova, Universidad de Cuenca, Ecuador James P. McNamara, Boise State University, United States

*Correspondence:

Paola A. Arias paola.arias@udea.edu.co

Specialty section: This article was submitted to Hydrosphere,

a section of the journal

Frontiers in Earth Science

Received: 16 October 2019 Accepted: 01 December 2020 Published: 18 February 2021

Citation:

Arias PA, Garreaud R, Poveda G, Espinoza JC, Molina-Carpio J, Masiokas M, Viale M, Scaff $L$ and van Oevelen PJ (2021) Hydroclimate of the Andes Part II: Hydroclimate Variability and Sub-

Continental Patterns.

Front. Earth Sci. 8:505467. doi: 10.3389/feart.2020.505467
This paper provides an updated review of the most relevant scientific literature related to the hydroclimate of the Andes. The Andes, the longest cordillera in the world, faces major challenges regarding climate variability and climate change, which impose several threats to sustainable development, including water supply and the sustainability of ecosystem services. This review focuses on hydroclimate variability of the Andes at a sub-continental scale. The annual water cycle and long-term water balance along the Andes are addressed first, followed by the examination of the effects of orography on convective and frontal precipitation through the study of precipitation gradients in the tropical, subtropical and extratropical Andes. In addition, a review is presented of the current scientific literature on the climate variability in the Andes at different timescales. Finally, open research questions are presented in the last section of this article.

Keywords: Andes, hydroclimate, hydrological cycle, climate variability, orographic precipitation

\section{INTRODUCTION}

Due to its latitudinal extension and its prominent topography, the Andes Cordillera is characterized by a wide variety of mountain climates, from very humid conditions like the cloud forest and paramo in the tropics and the western Patagonia in the extratropics, to the hyper arid conditions in the subtropics, like the Atacama Desert. The Andes provides ecosystem services, such as the provision of fresh water to near 90 million people in seven countries (Venezuela, Colombia, Ecuador, Peru, Bolivia, Chile and Argentina) (Schoolmeester et al., 2018). At the same time, the Andes range sets the stage for the occurrence of disasters due to the presence of steep terrains, hydrometeorological extreme events that are exacerbated by hydroclimate variability, climate change, deforestation and land use changes (Poveda et al., 2020).

Given the importance of the Andes in terms of biodiversity and ecosystem services provided to largely populated regions in South America, an adequate understanding of the regional hydroclimate is mandatory. Few studies have provided comprehensive reviews of current knowledge regarding the hydroclimate variability in the Andes. Among them, Rabatel et al. (2013), Vuille et al. (2018), and Masiokas et al. (2020) focused on the Andean cryosphere. In addition, Berbery and Barros (2002) 
described the hydrologic cycle of the La Plata basin in Southeastern South America. Marengo and Espinoza (2016) reviewed the hydroclimatic variability of the Amazon river basin, including the eastern flank of the Andes, with a particular emphasis on observed and projected extreme hydrological events.

The current study is part of a series of review papers focused on the diverse aspects of climate, weather, hydrology and cryosphere of the Andes cordillera. Among them, PabónCaicedo et al. (2020) provided a review on observed and projected changes in the hydroclimate of the Andes including temperature and precipitation variability in the Andes throughout the last two millennia. Poveda et al. (2020) reviewed the climatological occurrence of high impact weather events in the Andes and Condom et al. (2020) discussed the current observational and monitoring hydrometeorological networks in the Andes. These reviews provide a state-of-theart synthesis of current knowledge, as part of the ANDEX initiative. ANDEX is a prospective Regional Hydrological Project (RHP) of the Global Energy and Water Cycle Exchanges (GEWEX; https://www.gewex.org/) project of the World Climate Research Program (WCRP; https://www.wcrpclimate.org/). For more details, see Part I (Espinoza et al., 2020).

In this study, recent advances regarding the Andean hydroclimate are assessed and discussed. An integrated overview from the northern Andes to Patagonia is taken into account. This study is presented in two parts. Part I (Espinoza et al., 2020) is dedicated to summarize the mean large-scale atmospheric circulation that characterizes the hydroclimate of the Andes and the annual cycles of precipitation and runoff. This second part addresses the hydroclimate variability of the Andes at a sub-continental scale. Here, the annual long-term water balance and the annual cycle of hydrological fluxes (precipitation and runoff) along the Andes are addressed. Then the effects of orography on precipitation through the study of precipitation gradients at low and mid-latitudes are discussed. Finally, the current knowledge on climate variability in the Andes at subseasonal, interannual and decadal timescales are presented.

\section{HYDROLOGICAL PROCESSES}

Surface hydrology in the Andes exhibits a variety of annual cycles along the entire cordillera. Following Espinoza et al. (2020), this paper is focused on the following subregions: north tropical Andes (north of $8^{\circ} \mathrm{S}$ ), south tropical Andes $\left(8^{\circ} \mathrm{S}-27^{\circ} \mathrm{S}\right)$, subtropical Andes $\left(27^{\circ} \mathrm{S}-37^{\circ} \mathrm{S}\right)$ and extratropical Andes (south of $37^{\circ} \mathrm{S}$ ). This section provides a review of the main features of the annual water cycle in the Andes, with focus on river discharges and its link to spatio-temporal behavior of rainfall presented in Espinoza et al. (2020). The contributions from glacier melting over the south tropical and extratropical Andes are also discussed.

\section{River Flows}

\section{Mean Annual River Flows}

The latitudinal and longitudinal contrasts that exist in the mean annual flows of the rivers originating in the Andes are clearly reflected in Figure 1. In the north tropical Andes and along the eastern portion of the south tropical Andes, the overall humid conditions result in numerous large to very large rivers with mean annual flows in the order of several hundreds or thousands of cubic meters per second. This is the case, for example, of most rivers draining the upper Amazon and Orinoco basins. Substantially lower flows and smaller rivers can be found on the western, drier portion of the south tropical Andes, where rivers reaching the coasts of Peru usually show mean annual values in the order of tens of cubic meters per second (Figure 1A). The contrast between the eastern and western basins is clearly evident along the southern sector of the south tropical Andes: the eastern margins of the Andes in Bolivia and northwestern Argentina are characterized by lush mountain rainforests ("yungas") drained by large rivers, but conditions change dramatically to the west, where the extreme arid conditions of the Atacama desert and adjacent regions in northern Chile only allow very few rivers and creeks with small annual flows in the order of 0.1-2 cubic meters per second (Figure 1A).

In some upper basins of the south tropical Andes, glacier melt can contribute to the river discharges. Soruco et al. (2015) showed that glaciers contribute around $15 \%$ of water resources to the La Paz city (Bolivia) annually, and 14 and 27\% during the wet and dry seasons, respectively. Buytaert et al. (2017) estimated the relative contribution of glacial melt to the water supply of selected main cities of the south tropical Andes characterized by different meteorological conditions, finding a mean annual glacier melt contribution of $2.2 \%$ in Quito (Ecuador), $<1 \%$ in Lima (Peru), and $19 \%$ in Huaraz (located in the upper Santa River basin in Peru). Glacier contribution to local water supply is clearly sensitive to the occurrence of extreme droughts, increasing its relevance during dry years when precipitation over the basin is reduced to a minimum (e.g., Dussaillant et al., 2019; Masiokas et al., 2020). The increasing frequency of these events, overlapped with the ongoing shrinking trend in Andean glaciers (Masiokas et al., 2020), will impact the resilience of the local water management systems in the future (Buytaert et al., 2017).

The flows of most rivers on both sides of the subtropical Andes show a strong dependence on seasonal accumulation and subsequent melting of snow in the upper basins (e.g., Masiokas et al., 2006). Here, the drier conditions in the northern basins support smaller rivers than further south, and the longitudinal contrasts between the eastern and western margins of the Andes are not as marked as described above for the south tropical Andes (Figure 1). Common mean annual values for the most important rivers in this region range between 10 and 150 cubic meters per second (Figure 1A). The Andes at these latitudes contain extensive areas covered by glaciers and permanent ice-rich permafrost features such as rock glaciers (Azócar and Brenning, 2010; Zalazar et al., 2017). Melt water from these ice masses can play an important hydrological role, as shown by a recent study of the Maipo river basin (Ayala et al., 2020). These authors estimated that between 1955 and 2016 glaciers contributed, on average, with ca. 37\% of the annual runoff of the basin. This glacier contribution can become especially important during extended dry periods such as those observed in the subtropical Andes region since 2010 (Garreaud et al., 2017; Rivera et al., 2017; Dussaillant et al., 2019). 
A

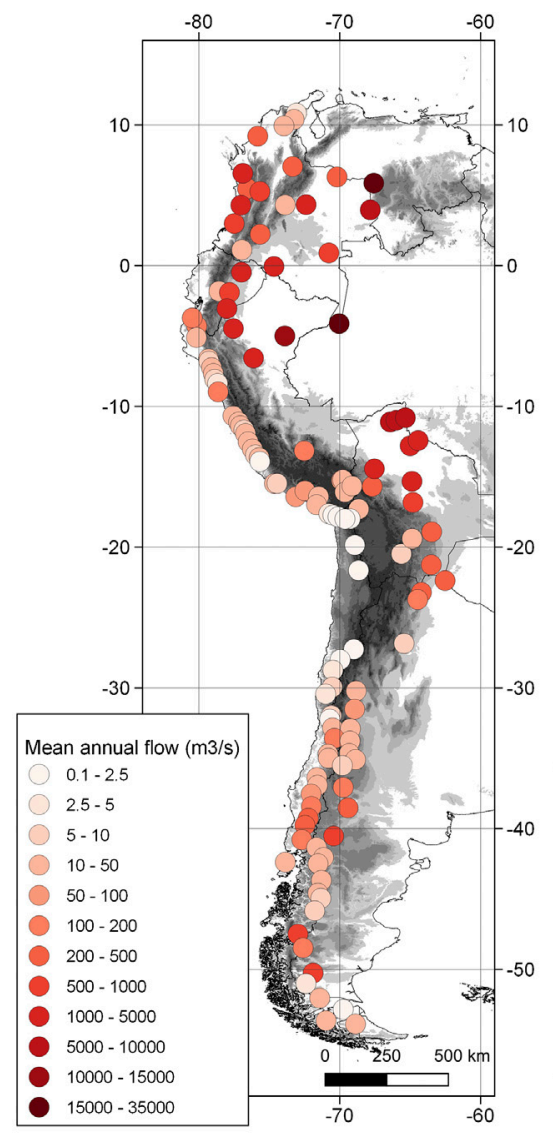

B

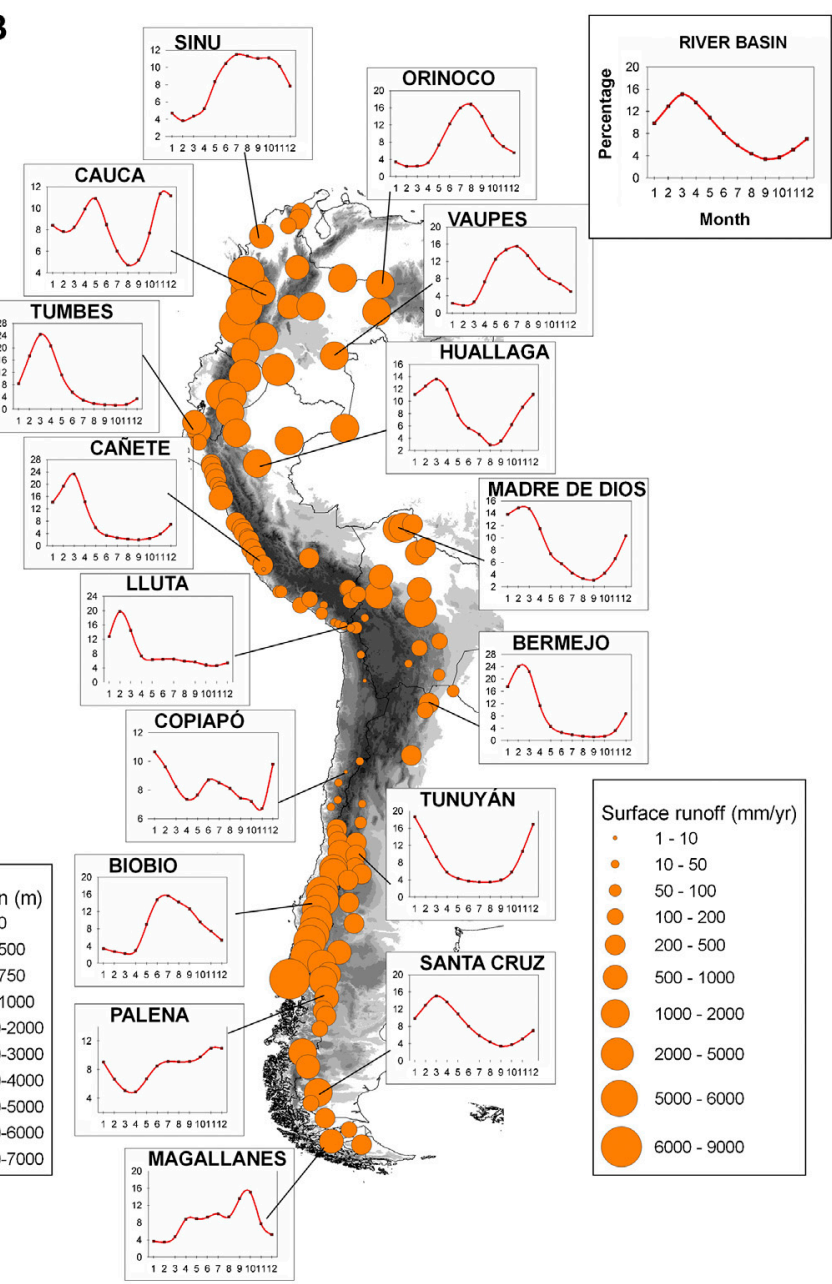

FIGURE 1 | (A) Mean annual streamflow for selected rivers along the Andes. (B) Mean annual surface runoff of the same selected rivers. The annual cycles (expressed as monthly percentages relative to the annual totals) are also shown for characteristic river basins to illustrate the marked contrasts that exist along the Andes. Note that these diagrams have different $Y$-axis scales to highlight the characteristic seasonal variability at each site. X-axis indicates the month of the year (from 1 : January to 12: December). Also note that as the period of records can vary among stations (Table 1), the values in the figure only provide an overall indication of the longterm mean annual and monthly conditions at each site.

To the south, the extratropical Andes in Patagonia and Tierra del Fuego are lower in elevation and conditions become more humid, usually resulting in larger river flows than those found immediately to the north (Figure 1A). Normal mean annual streamflow values can reach several tens to a few hundreds of cubic meters per second for the largest rivers. These values usually depend on the variable amounts of solid and liquid precipitation that falls in the upper basins. In these regions, few cases exist where the glacier cover is extensive enough to have a discernible signal in the annual river flows (Pasquini and Depetris, 2007; Pasquini and Depetris, 2011; Masiokas et al., 2019).

\section{Seasonal Variations in River Flows}

The north tropical Andes exhibits unimodal or bimodal regimes on river discharge that respond to the annual cycle of precipitation in the different sectors (see Espinoza et al. (2020) and Figure 1B). In Colombia, many river basins located north of the Andes exhibit a bimodal annual cycle with two wet seasons (April-May and September-November; see e.g., the Cauca river in Figure 1B) associated with similar patterns in rainfall, evapotranspiration and soil moisture (Mejia et al., 1999; Poveda, 2004; Poveda et al., 2011; Urrea et al., 2019). The bimodal annual cycle of rainfall on the Andes of Colombia results from the combination of the meridional oscillation of the Intertropical Convergence Zone (ITCZ), atmospheric moisture advection by the Choco, Caribbean and Orinoco low-level jets, and strong land surface-atmospheric interactions (Poveda et al., 2014, Poveda et al., 2020; Arias et al., 2015; Hoyos et al., 2017; Bedoya-Soto et al., 2019; Espinoza et al., 2020). Rivers along the Colombian Pacific coast, such as the San Juan river, show discharge peaks around October-November (VelásquezRestrepo and Poveda, 2019). This pattern is similar to that shown by the Sinu river further north (Figure 1B).

Rivers of the eastern Andean basins in Colombia and Ecuador, in contrast, are characterized by unimodal cycles with peaks in 
TABLE 1 | General information of the selected runoff gauges corresponding to the mean annual cycles shown in Figure 1B.

\begin{tabular}{|c|c|c|c|c|c|c|}
\hline Id & Country & Station & Lat & Lon & Elevation (m.a.s.l) & Period \\
\hline BERMEJO & Argentina & BERMEJO-POZO SARMIENTO & -23.22 & -64.20 & 296 & 1986-2015 \\
\hline TUNUYAN & Argentina & TUNUYAN-VALLE DE UCO & -33.78 & -69.27 & 1,200 & 1986-2015 \\
\hline SANTA CRUZ & Argentina & SANTA CRUZ-CHARLES FUHR & -50.27 & -71.89 & 206 & 1986-2015 \\
\hline PALENA & Argentina & CARRENLEUFU-LA ELENA & -43.68 & -71.30 & 783 & 1986-2015 \\
\hline MADRE DE DIOS & Bolivia & MIRAFLORES & -11.11 & -66.41 & 125 & 1985-2013 \\
\hline LLUTA & Chile & LLUTA EN ALCERRECA & -18.00 & -69.63 & 3,550 & 1986-2015 \\
\hline COPIAPO & Chile & COPIAPO EN PASTILLO & -28.00 & -69.97 & 1,300 & 1986-2015 \\
\hline $\mathrm{BlO}$ & Chile & DUQUECO EN VILLUCURA & -37.55 & -72.03 & 228 & 1986-2015 \\
\hline MAGALLANES & Chile & SAN JUAN EN DESEMBOCADURA & -53.65 & -70.97 & 8 & 1986-2015 \\
\hline SINU & Colombia & PALMA CENTRAL & 9.20 & -75.82 & 6 & 1991-2010 \\
\hline CAUCA & Colombia & IRRA & 5.27 & -75.67 & 745 & $1972-2013$ \\
\hline ORINOCO & Colombia & RONCADOR & 5.86 & -67.58 & 62 & 1991-1998 \\
\hline VAUPES & Colombia & LOS CERROS & 0.90 & -70.77 & 195 & 1990-2013 \\
\hline TUMBES & Perú & EL TIGRE & -3.72 & -80.47 & 40 & 1969-2004 \\
\hline CAÑETE & Perú & SOCSI & -13.03 & -76.2 & 330 & 1969-2004 \\
\hline HUALLAGA & Perú & CHAZUTA & -6.57 & -76.12 & 150 & 1986-2010 \\
\hline
\end{tabular}

July-August (see e.g., the Orinoco and Vaupes rivers in Figure 1B; Laraque et al., 2007; Arrieta-Castro et al., 2020). These unimodal regimes are associated with low advective shallow clouds causing precipitation, influenced by the advection of water vapor from the Amazon basin and enhanced easterlies during boreal summer (Campozano et al., 2016; Segura et al., 2019). The Ecuadorian Andes, however, also exhibit a large spatial variability in river discharge seasonality and cases with bimodal annual cycles peaking around March-April and October can be found in many intra-Andean basins (Laraque et al., 2007; Campozano et al., 2018). In the lowlands of these intra-Andean basins, the discharge peaks around June-July and October-November (Laraque et al., 2007). These patterns reflect the occurrence of bimodal rainfall regimes, with dry conditions during boreal summer, caused by strong subsidence that inhibits the formation of convective clouds (Campozano et al., 2016; Segura et al., 2019). Rivers of the western Andean basins in Ecuador and northern Peru are characterized by a unimodal pattern with peaks around March-April (see Tumbes river in Figure 1B). In this region, the wet season occurs from late December through May, corresponding to the southerly position of the ITCZ (Recalde-Coronel et al., 2014; Rau et al., 2017; Segura et al., 2019).

In the south tropical Andes, the seasonal discharges are usually characterized by unimodal cycles peaking between January and March along both the eastern and western flanks of the mountain range (Figure 1B). This pattern reflects the occurrence of the rainy and the dry seasons in December-March and June-August, respectively, and is partly associated with the South American Monsoon (see Espinoza et al. (2020) and Influence of the Andes Topography on Precipitation; also Vera, 2006; Espinoza et al., 2011; Lavado-Casimiro et al., 2012; Rau et al., 2017; MolinaCarpio et al., 2017). This relatively consistent unimodal seasonal pattern can be observed in the hydrographs of the Cañete and Lluta river basins along the western, drier portion of the region, and also in the records from the Huallaga, Madre de Dios and Bermejo rivers, located in the upper and much wetter Amazon and La Plata river basins (Figure 1B).
In the high subtropical Andes, precipitation usually falls as snow in winter and remains frozen until the onset of the melting season in the spring (October-November). In this sector, most rivers on both sides of the Andes show a unimodal snowmeltdominated regime with a peak during the warmer months in December-January (see e.g., the Copiapó and Tunuyán rivers in Figure 1B; and Masiokas et al., 2006, 2019). Further south in Patagonia and Tierra del Fuego, the extratropical Andes are exposed to the westerlies during most of the year (Garreaud, 2009; Garreaud et al., 2013). This results in a more uniform seasonal distribution of precipitation with mixed contributions of rain and snow, depending on the annual cycle of temperatures and the overall elevation of the different sectors. Rivers in these regions reflect this rather complex hydroclimatic nature of the Andes: some sectors show a single discharge peak due to the higher precipitation levels in winter (e.g., the Bio river in Figure 1B), while others also show a peak in spring-early summer due to snowmelt (e.g., the Palena and Magallanes basins, Figure 1B; see also Pasquini and Depetris, 2007; Lara et al., 2008; Mundo et al., 2012; Krogh et al., 2015; Masiokas et al., 2019). The two largest rivers of this southernmost portion of the Andes are the Baker and the Santa Cruz rivers, which drain extensive parts of the north and nouth Patagonian Icefields, respectively. The Santa Cruz river, in particular (see Figure 1B), drains ca. $3,000 \mathrm{~km}^{2}$ of glaciated areas and shows a discernible peak in the late summer-early fall largely due to the contribution of ice melt (Pasquini and Depetris, 2007; Pasquini and Depetris, 2011; Masiokas et al., 2019).

\section{Evapotranspiration}

The exceptional height of the Andes Mountains conditions the atmospheric circulation at low elevations, and clearly divides the atmospheric moisture sources east and west of the water divide. The Atlantic Ocean as well as the Orinoco, Magdalena and Amazon River basins are the main oceanic and continental water vapor sources for most of the tropical Andes (Sakamoto et al., 2011; Arias et al., 2015; Hoyos et al., 2017) and neighboring regions such as the Altiplano and the Andean part of the La Plata 
River basin (Garreaud, 1999; Garreaud et al., 2003; Falvey and Garreaud, 2005; Martinez and Dominguez, 2014; Staal, 2018; Sori et al., 2019; Segura et al., 2020), through the low-level moisture transport. The important Amazon source means that the hydrological cycle and water balance of the tropical Andes system could be particularly sensitive to Amazon land-cover change (see Espinoza et al., 2020). The Pacific Ocean is an important atmospheric moisture source for the western Andes of Colombia (Sakamoto et al., 2011; Arias et al., 2015; Hoyos et al., 2017), northern Peruvian and Ecuadorian Andes (Segura et al., 2019), and the main source for the subtropical and extratropical regions of Argentina and Chile (Garreaud et al., 2009).

If changes in storage over time are considered negligible in the long term, the surface (SWB) and atmospheric (AWB) water balance become, respectively:

$$
\begin{aligned}
& \langle R\rangle=\langle P\rangle-\langle E\rangle \\
& \langle C\rangle=\langle P\rangle-\langle E\rangle
\end{aligned}
$$

where $\mathrm{P}$ is precipitation rate $\left[\mathrm{LT}^{-1}\right], \mathrm{E}$ is evapotranspiration rate $\left[\mathrm{LT}^{-1}\right], R$ is runoff rate $\left[\mathrm{LT}^{-1}\right]$ and $C$ is the net moisture convergence (or the moisture that is stored in the atmosphere) ( $C=-\Lambda \mathrm{Q}$, where $\Lambda \mathrm{Q}$ is the net vertically integrated moisture divergence). \langle\rangle denotes the long-term mean (Builes-Jaramillo and Poveda, 2018).

Recent water balance estimates by Builes-Jaramillo and Poveda (2018) show that for the Andes-Amazon system, the water balance components are of the same order of magnitude (Figure 2 of Espinoza et al., 2020). In spite of receiving less precipitation, runoff is higher in the Andean rivers than in the lowland Amazon (Moquet, 2011). This is probably related to the Andes-Amazon spatial rainfall variability. The rainiest Amazon basin regions ("hotspots") occur in the Andes (Espinoza et al., 2015; Chavez and Takahashi, 2017), and also the presence of steep topography that favors higher runoff (Espinoza et al., 2014). Large negative residuals $(\mathrm{P}-\mathrm{E}-\mathrm{R}<0)$ were detected in two important Andean sub-catchments: Borja (Marañón River) and Rurrenabaque (Andean Beni River) for both the surface and atmospheric water balance. As the uncertainty of runoff records is relatively low, the SWB imbalance in these basins reflects mainly the high spatial variability of $\mathrm{P}$ and $\mathrm{E}$ (particularly the former) and the low density of meteorological networks. The AWB imbalance (both internally and related to SWB) reflects the uncertainties in the reanalysis data source (Builes-Jaramillo and Poveda, 2018). SWB negative residuals have been also found for many smaller Andean basins (Molina-Carpio et al., 2007; LavadoCasimiro et al., 2012), suggesting that the study of the components of the water balance in the Andes remains an important research topic. In this sense, the different issues that need to be addressed to better understand the hydrological cycle in the Andes are: 1) the spatial variability of precipitation at different spatial scales and the associated causes (see the following sections); 2) the low density of rainfall and runoff observations in the region (Condom et al., 2020); 3) the generalized lack of permanent atmospheric sounding stations, meteorological radars, and other atmospheric observations (Condom et al., $2020)$; 4) the combined roles of diverse atmospheric low-level jets and atmospheric rivers in the transport of atmospheric moisture to the Andes (e.g., Sakamoto et al., 2011; Arias et al., 2015; Chavez and Takahashi, 2017; Hoyos et al., 2017; Kumar et al., 2019; Segura et al., 2020); 5) evapotranspiration and moisture recycling processes from the rainforest to the Andes (e.g, Molina et al., 2019; Ampuero et al., 2020; Ruiz-Vasquez et al., $2020)$; 6) the high amounts of precipitation recycling in the tropical Andes (70-90\%) (e.g., Zemp et al., 2014; Zemp et al., 2017; Staal, 2018); 7) the land-atmosphere interactions in the Andes (e.g., Saavedra et al., 2020); 8) the role of groundwater processes in the Andes (karts dynamics, for instance) and its influence on surface hydrology and sediment transport processes (e.g., Tovar Pacheco et al., 2006; Ayes Rivera et al., 2003-2016; Olarinoye et al., 2020); 8) the effects of climate change, deforestation, and land use changes on different water fluxes and storages along the Andes (e.g., Pabón-Caicedo et al., 2020); 9) the physical processes controlling the formation of floods and droughts along the Andes; among others.

\section{Long-Term Water Balance}

The mean annual value of reference evapotranspiration $\left(\mathrm{ET}_{0}\right)$ (i.e. the rate at which water, if available, would be removed from the soil and plant surface of a specific crop (FAO, 1998)), ranging from 900 to more than $2000 \mathrm{~mm} / \mathrm{yr}$, is greater than annual precipitation in the Altiplano region (Chaffaut, 1998; MolinaCarpio et al., 2014). In the northern Altiplano, the Lake Titicaca plays an important regulation role for the local climate and hydrology. In the arid southern Altiplano, extremely arid northern Chile and northwestern Argentina, which are the regions on Earth that receive the greater net solar radiation (e.g., Rondanelli et al., 2015), $\mathrm{ET}_{0}$ is at least one order of magnitude bigger than precipitation (Molina-Carpio, 2007). In most of these regions, runoff can only occur in relation to groundwater storage (aquifers). Thus, more than 95\% of surface water comes from groundwater dated to some thousands of years (Aravena, 1995; Chaffaut, 1998; MolinaCarpio, 2007).

Furthermore, the Altiplano is very sensitive to climate (Coudrain et al., 2002; Garreaud et al., 2003) and anthropogenic changes (Minvielle and Garreaud, 2011; Satgé et al., 2017). Even small changes in the water cycle components can put at risk the Altiplano hydrological and natural systems and its population. Given the lack of outlet drainage, the surface water storage in endorheic catchments depends critically on the equilibrium among precipitation, evapotranspiration and groundwater exchange. This equilibrium is affected, for example, by increases in agricultural land and irrigation in the Altiplano, which intensifies evapotranspiration water losses (Torres-Batló et al., 2020). Evaporation from lakes and soils may also be exacerbated by warming temperatures, which is a trend already detected for the region (Hunziker et al., 2018). In a recent study, Segura et al. (2020) documented that rainfall variability over the Altiplano is also modulated by deep convection in the western Amazon, particularly since 2000. All this highlights the urgent need for proper water management at the basin scale. 


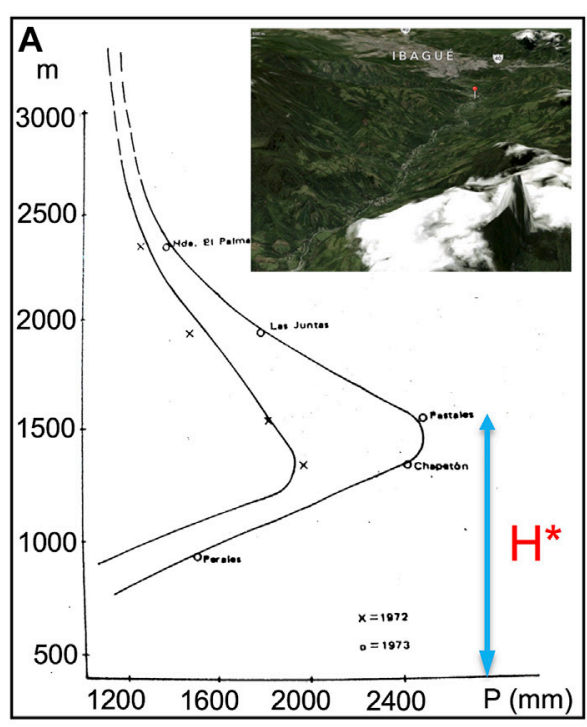

B

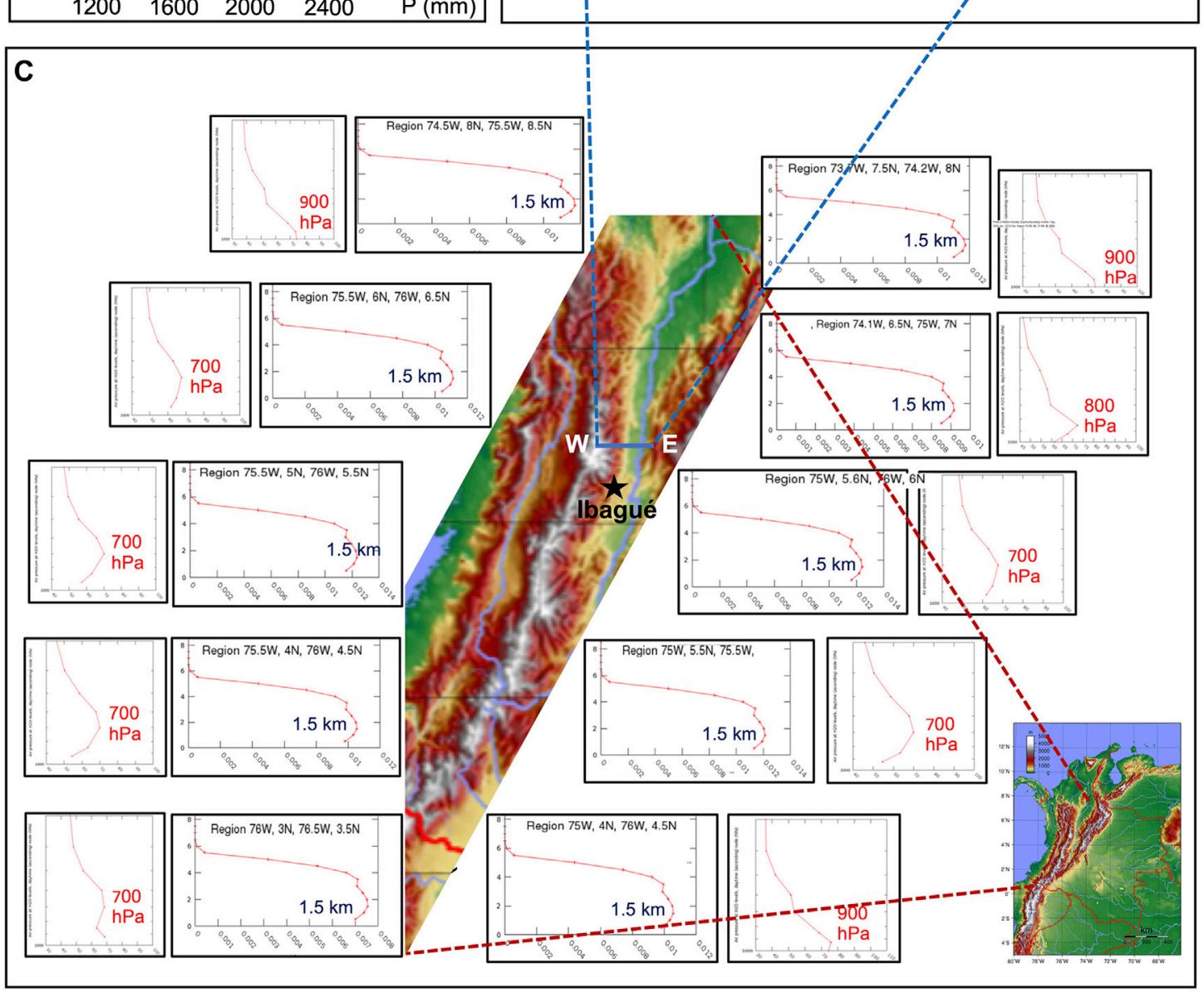

FIGURE 2 | (A) Distribution of rainfall with elevation during 1972 and 1973 along the western slope of the intra-Andean valley of the Combeima River basin, located along the eastern slope of the Central range of Colombian Andes. Adapted from Oster (1979). The inset shows the Combeima River valley and the city of Ibagué, denoted with a black star on panel (C). Source: Google Maps. (B) Distribution of long-term mean annual rainfall with elevation and distance to the floor of the Magdalena River valley along the eastern slope of the Central Andes of Colombia around $5^{\circ} \mathrm{N}$ (W-E transect on panel (C). Adapted from Oster (1979). (C) Vertical cross-sections of long-term mean TRMM rainfall data (3A12 V7) and relative humidity (AIRX3STM v006), along diverse transects over the western and eastern slopes of the Central Andes of Colombia. These figures were produced using the Giovanni online tool (https://giovanni.gsfc.nasa.gov/giovanni/). 
Considering the large spatial variability of water availability on both sides of the Peruvian Andes, actual evapotranspiration shows high differences according to the relative magnitude of the local water balance components. Few studies have estimated evapotranspiration in the Peruvian Andes. For instance, LavadoCasimiro et al. (2011), using the modified Hargreaves-Samani method, found a mean annual evapotranspiration of $564 \mathrm{~mm} / \mathrm{yr}$ and $996 \mathrm{~mm} / \mathrm{yr}$ in the Vilcanota and Urubamba river basins (Cuzco), respectively. In the Mantaro basin (central Peruvian Andes), these authors estimate that the mean annual evapotranspiration is $648 \mathrm{~mm} / \mathrm{yr}$. Due to increased water availability in the Amazonian region, evapotranspiration increases, reaching $1,230 \mathrm{~mm} / \mathrm{yr}$ and $1,030 \mathrm{~mm} / \mathrm{yr}$ in average over the Ucayali and Huallaga basins, respectively (LavadoCasimiro et al., 2011). In the basins of the arid Pacific coast of Peru, evapotranspiration varies from 300 to $500 \mathrm{~mm} / \mathrm{yr}$, with the greatest values in the Moche and upper Santa river basins in the central Peruvian Andes (Rau et al., 2017). Using a set of meteorological sensors of latent heat fluxes installed in a gradient tower $30 \mathrm{~m}$ high in the Huancayo observatory (central Peruvian Andes, 3,312 m.a.s.l.), Flores-Rojas et al. (2019a) show a clear annual cycle of latent heat fluxes with monthly maximum in February-March and monthly minimum in June-July. In the Peruvian Pacific drainage, $\mathrm{ET}_{0}$ is higher than precipitation over most of the year (with exception of the December-March rainy season). Consequently, river runoff in the central and southern Pacific basins occurs most of the year in relation to changes in groundwater storage and, in some cases, to glacier contributions (Buytaert et al., 2017). In relation to these hydrological characteristics, agriculture over this region is highly dependent on national special irrigation projects that regulate the annual water availability (e.g., ANA, 2012). In the arid Pacific coast of Peru, groundwater is largely exploited for supply to the population and agriculture, such as the case of Lima and Ica regions (Tovar Pacheco et al., 2006). In the Peruvian Andes, UNESCO (2006) estimated that the available surface water (difference between rainfall and evapotranspiration) is $16.5 \mathrm{~mm} / \mathrm{yr}$ in the basins of the Pacific watershed, $130 \mathrm{~mm} / \mathrm{yr}$ in the Titicaca basins, and 2,700 mm/yr in the Peruvian Amazon, considering the 1969-2009 period.

In the extremely dry environment of the subtropical Andes, snow accumulated over altitudes above 2000 m.a.s.l is subject to high levels of intensive sublimation, a process that represents a significant loss of water for this semiarid region. Unfortunately, the lack of micro-meteorological data in this region precludes a detailed assessment of sublimations rates, as reported by Réveillet et al. (2019). The contribution of melt and sublimation to total ablation has been studied at both the point-scale (MacDonell et al., 2013) and catchment scale (Gascoin et al., 2013) in one catchment in the semi-arid Andes. MacDonell et al. (2013) estimated that the sublimation fraction was $90 \%$ of total ablation at altitudes above 5,000 m.a.s.l., in an extreme environment with predominantly sub-freezing temperatures and strong local wind speeds. On the basis of snow modeling, Gascoin et al. (2013) found that the total contribution of sublimation to total ablation in the Pascua-Lama area $\left(29.3^{\circ} \mathrm{S}\right.$, $70.1^{\circ} \mathrm{W} ; 2,600-5,630$ m.a.s.l.) was $71 \%$.

\section{INFLUENCE OF THE ANDES TOPOGRAPHY ON PRECIPITATION}

The Andes exhibits a complex topography that induces spatiotemporal hydroclimate variability at different scales. In particular, precipitation in the Andes is strongly influenced not only by the large-scale weather patterns, including the low-level jets (as described in Espinoza et al., 2020), but also by the interaction of these atmospheric moisture fluxes with orography. This section reviews the main orographic effects on convective (over the tropics and the subtropics) and frontal (over the subtropics and the extratropics) precipitation in the Andes.

\section{Orographic Effects on Convective Precipitation Systems in the Tropical and Subtropical Andes}

The orography of the Andes plays a key role on the initiation and evolution of convective precipitation systems, which dominate over and around the tropical and subtropical Andes. The orography strongly modulates the availability of atmospheric moisture and contributes ascending air masses aloft the mountain range, two key ingredients for convection initiation year-round in the tropics and during summer in the subtropics. Terrain-forced and thermally driven diurnal mountain winds are the two main forms of orographic lifting by which topography influences convective activity (e.g., chapters 2 and 3 of Chow et al., 2013). Terrain-forced winds occur when large-scale circulation, normally continental easterly winds in the tropics, encounter the topography and are forced to ascent following the shape of the terrain. The origin of thermal diurnal mountain winds is the strong solar radiation heating on the surface, which in turn induces temperature gradients that generate the diurnal circulations between the air immediately above the mountain terrain, and the air surrounding the mountain terrain at the same level. As a general rule, air moves upward (anabatic winds) during daytime from lower sectors, adjacent plains and valley floor, to higher elevations of the mountain range, following the slope and valley shapes (Bedoya-Soto et al., 2019). The opposite behavior occurs during late afternoon and nighttime (katabatic winds) (e.g., Lopez and Howell, 1967; Bendix et al., 2009; Junquas et al., 2018). Over inter-Andean valleys, there is a strong nonmonotonic relationship between precipitation and altitude above the valley floor. Annual precipitation increases with elevation, reaching a maximum at an altitude known as the "Pluviometric Optimum" (PO), and decreasing upwards (Oster, 1979). The PO is observed at both tropical and subtropical regions in the Andes. As an illustration, Figure 1A shows the distribution of precipitation with elevation along the western flank of the Combeima River basin, located on the eastern slope of the central Andes of Colombia (approximately at $75^{\circ} \mathrm{W}, 4^{\circ} \mathrm{N}$ ), during the years 1972 and 1973. The elevation of the PO denoted as $\mathrm{H}^{*}$ shows variability among consecutive years, within an altitudinal range of several hundred meters. At monthly timescales, the situation is much more complex. Thus, analyses of long-term mean data are required in order to better understand the governing processes. Figure 1B shows 
the distribution of long-term mean annual precipitation along the eastern slope of the central Andes of Colombia around $5^{\circ} \mathrm{N}$, with respect to elevation and distance to the floor of the Magdalena River valley. The PO is located at the elevation of the Fresno rain gauge. But here too the situation is much more complex. For instance, an in-depth analysis indicates the presence of two POs or even the presence of a pluviometric minimum along different transects of the intra-Andean valleys of the Colombian Andes (Oster, 1979; Poveda et al., 2019). Such strong local and regional variability observations constitute an excellent ground truth for validating convection-permitting models in tropical mountain settings. The challenge is also valid for satellite rainfall, given, for instance, the low-skill of the TRMM data in capturing rainfall over the Andes of Colombia (Vallejo-Bernal et al., 2020). Figure 1C shows the long-term mean vertical distribution of rainfall and relative humidity across diverse transects along the central Andes of Colombia. Rainfall data corresponds to TRMM $3 \mathrm{~A} 12 \mathrm{~V} 7$, at a $0.5^{\circ}$ spatial resolution, for the period spanning from December 1997 to March 2015. Relative humidity corresponds to AIRS (AIRX3STM v006) data on board the Aqua satellite, from January 2003 to December 2015 (Poveda et al., 2019). The panels in Figure 1C evidence that TRMM satellite rainfall is able to capture important differences in the vertical distribution of rainfall, although rather simplistically given that it locates the $\mathrm{PO}$ everywhere at $1,500 \mathrm{~m}(\sim 850 \mathrm{hPa})$, and that AIRS data show a maximum amount of relative humidity around $700 \mathrm{hPa}$, suggesting the existence of a relative humidity optimum at that height, which deserves further investigation.

Local wind circulations contribute to explain the PO location, as well as the strong variability found in the diurnal cycle of rainfall in the Andes of Colombia (Poveda et al., 2005). A simplified depiction of the predominant nocturnal and diurnal wind circulations $\left(4^{\circ} \mathrm{N}-5^{\circ} \mathrm{N}\right)$ is shown in Figure 2A. In addition, transects of long-term mean annual precipitation across the three ranges of the Colombian Andes around $6^{\circ} \mathrm{N}$, shown in Figure 2 (reproduced from Alvarez-Villa et al., 2011), clearly illustrates some of the above-mentioned orographic effects. For instance, the nearly constant value of long-term mean annual precipitation over the flat terrain of the Orinoco region differs from the largely variable values within the Andes. Also, the two greatest values are observed on both slopes of the outermost ranges, which receive important atmospheric moisture contributions from Amazonia and the Pacific Ocean. The lowest values coincide with the valley floors within the Andes cordillera.

Past studies (Oster, 1979; Alpert, 1986) indicate that the location of the PO depends on diverse factors, such as: 1) altitude of the valley floor and mountain top above sea level, 2) absolute humidity, 3) local air circulations, 4) evapotranspiration on the valley floor, 5) temporal scale of analysis, 6) presence of pre-orographic rains, and 7) the corresponding landform, valley or hillside. Precipitation below the PO is lower due to less evaporative input, and above the PO due to a decrease in air humidity with altitude. Depending on the orography and altitude of the mountaintop, a secondary (sometimes primary) maximum could occur over the same mountain range at higher elevations (Roche et al., 1990;
Molina-Carpio et al., 2019). The association of a PO at 2,700-3,500 m.a.s.l with the existence of the perhumid cloud forest and subparamo ecoregions within the tropical Andes is of particular interest for Andean hydrologists and biologists. The relative dominance of regional or local air circulation patterns has been recently identified as a key factor for the location (elevation) of the PO and it can also be related with the precipitation and wind diurnal cycles (Chavez and Takahashi, 2017; Molina-Carpio et al., 2019). A thorough understanding of the location and variability of the PO constitutes a fundamental scientific challenge.

At the dry western flank of the Peruvian Andes, mean annual rainfall is estimated to be about $15-20 \mathrm{~mm} / \mathrm{yr}$ below the 500 m.a.s.l, but this value increase slightly up to $90 \mathrm{~mm} / \mathrm{yr}$ in the northern Pacific coast of Peru. The large-scale subsidence related to the downward motion of the Walker circulation is the primary cause of the stable and dry conditions along the Pacific Peruvian coast (Houston and Hartley, 2003; Takahashi and Battisti, 2007; Garreaud, 2009). Above the inversion layer, rainfall is generally more abundant (Dollfus, 1964; Johnson, 1976) but very little rainfall may also be recorded at high altitude (Lavado-Casimiro et al., 2012; Rau et al., 2016). Annual precipitation can exceed $1,000 \mathrm{~mm} / \mathrm{yr}$ around 1,000-3,000 m.a.s.l on the western slopes of the Peruvian Andes. Above 3,000 m.a.s.l, however, rainfall ranges from 500 to $750 \mathrm{~mm} / \mathrm{yr}$ (Figure 3) (Lavado-Casimiro et al., 2012; Rau et al., 2016).

At the eastern flank of the tropical Andes, the windward or leeward exposure of the rain gauges to the dominant moist wind generates a more complex relationship between rainfall and altitude (Johnson, 1976; Roche et al., 1990; Guyot, 1993; Pulwarty et al., 1998; Buytaert et al., 2006; Ronchail and Gallaire, 2006; Laraque et al., 2007; Bookhagen and Strecker, 2008; Espinoza et al., 2009b; Espinoza et al., 2009a; Rollenbeck and Bendix, 2011). Extreme rainfall occurs generally at locations that favor strong air uplift, as Churuyacu (500 m.a.s.l; 5,500 mm/ yr) in Colombia, close to a steep slope, and Reventador (1,470 m.a.s.l; 6,200 mm/yr), a remote volcano in the AndeanAmazon transition region in Ecuador. Over the Ecuadorian and northern Peruvian Amazon-Andes region, the convergence of nocturnal drainage down the eastern slope of the Andes, interacting with the warm moist air from the Amazon basin, triggers mesoscale convective systems (MCS; Bendix et al., 2009; Trachte et al., 2010a; Trachte et al., 2010b; Trachte and Bendix, 2012; Kumar et al., 2020a). In addition, the occurrence of katabatic flows during nighttime interacting with the concave terrain in the south tropical Andes of Ecuador cause the development of surface cold fronts, initiating the ascent of air masses to its lifting condensation level and the formation of cloud clusters (Bendix et al., 2009; Trachte et al., 2010a; Trachte et al., 2010b; Trachte and Bendix, 2012).

In the eastern flank of the south tropical Andes and the western Amazonia, high rainfall rates of around 4,000-7,000 mm/yr are observed in windward conditions (e.g., Quincemil, San Gabán and Chipiriri stations, Figure 4). Orographic effects and the exposure to easterly winds produce a strong annual rainfall gradient between the lowlands and the 


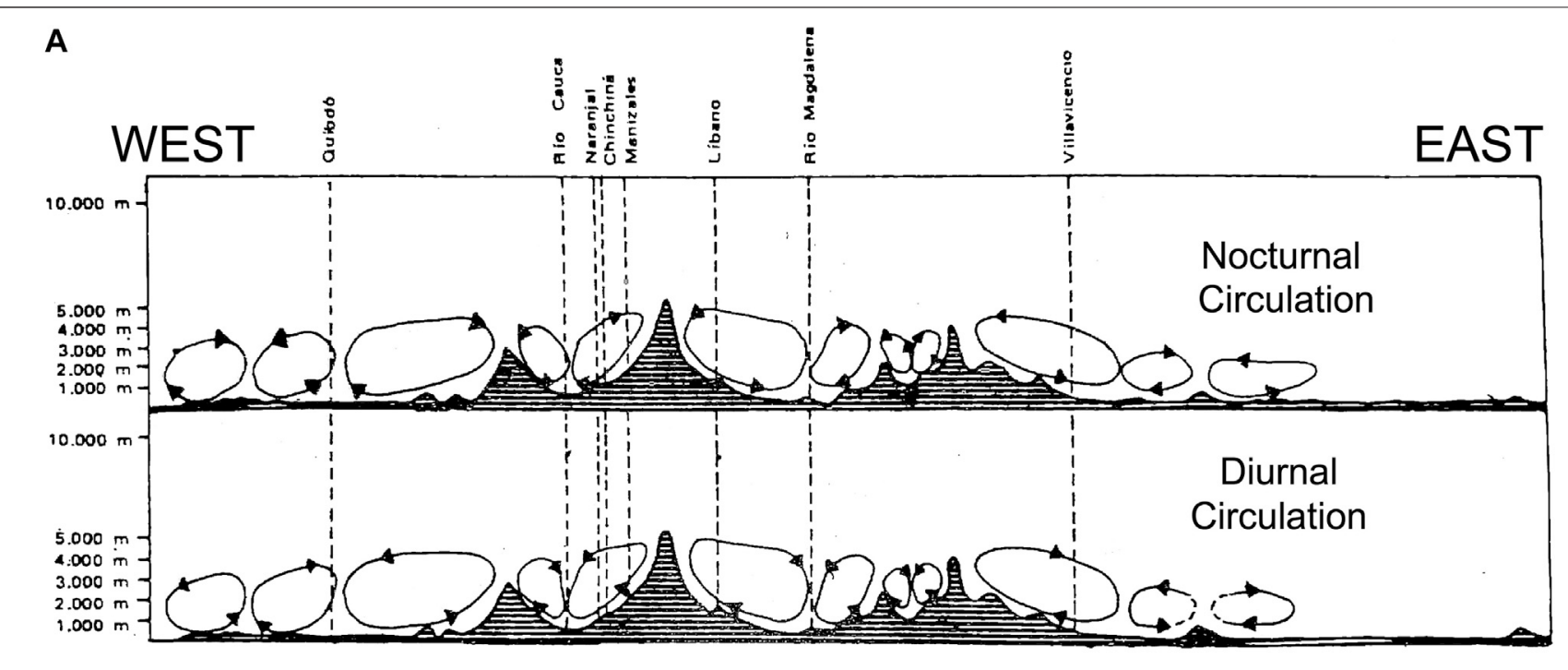

B
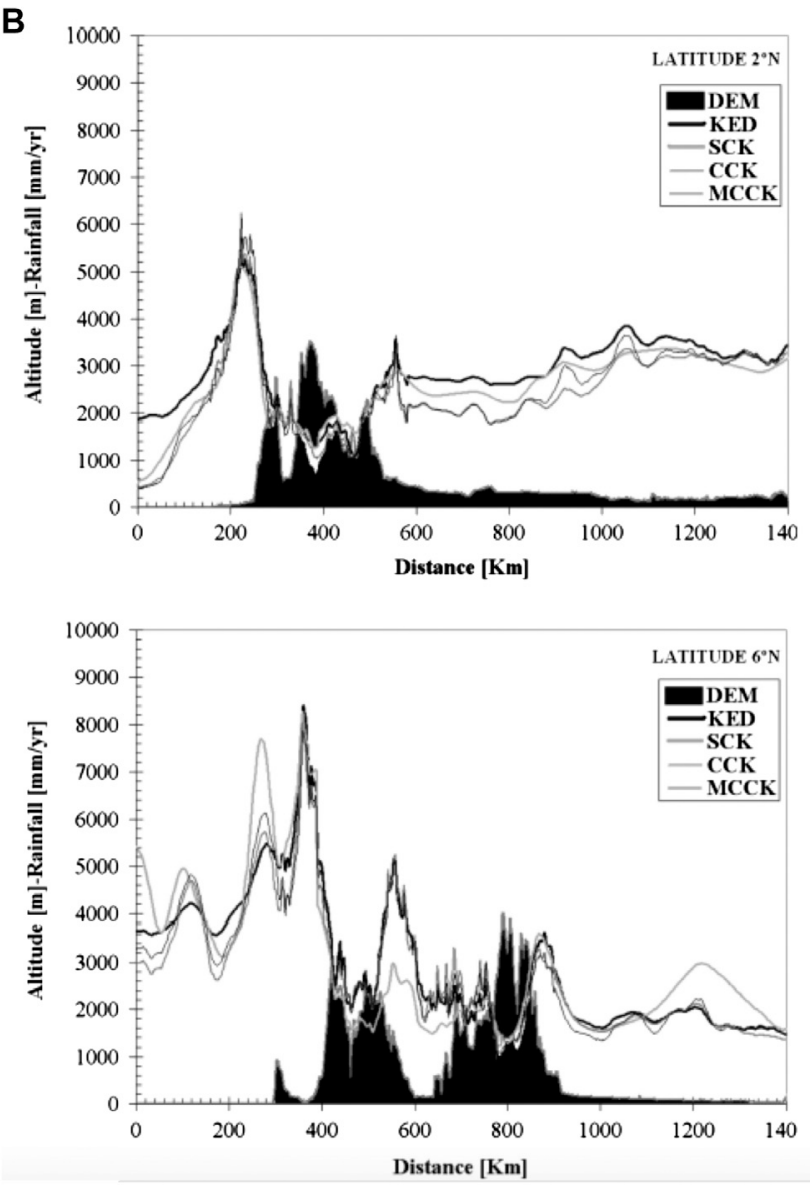
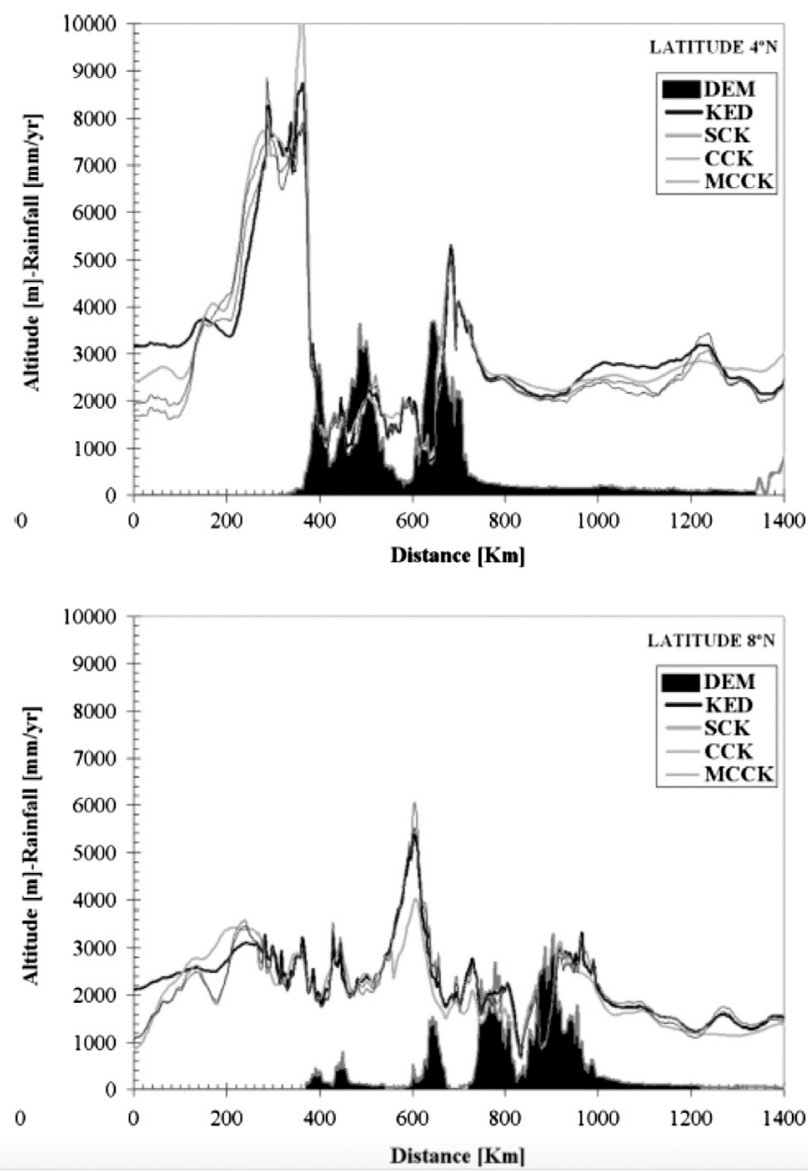

FIGURE 3 | (A) Schematics of local wind circulations among the intra-Andean valleys of the three ranges of the Colombian Andes during night (top) and day (bottom). Adapted from Oster (1979). (B) Distribution of the long-term mean annual rainfall along four transects $\left(2^{\circ} \mathrm{N}, 4^{\circ} \mathrm{N}, 6^{\circ} \mathrm{N}, 8^{\circ} \mathrm{N}\right)$ covering the three ranges of the Colombian Andes (filled in black), showing the location of the pluviometric optima in the intra-Andean valleys. Results were obtained using diverse variants of Kriging interpolation at 4-km resolution for all Colombia, denoted with different line types, with information from 1,180 rain gauges covering the period 1950-2005, and satellite data from the tropical rainfall measuring mission (TRMM) for the period 1999-2005. Source: Alvarez-Villa et al. (2011). 


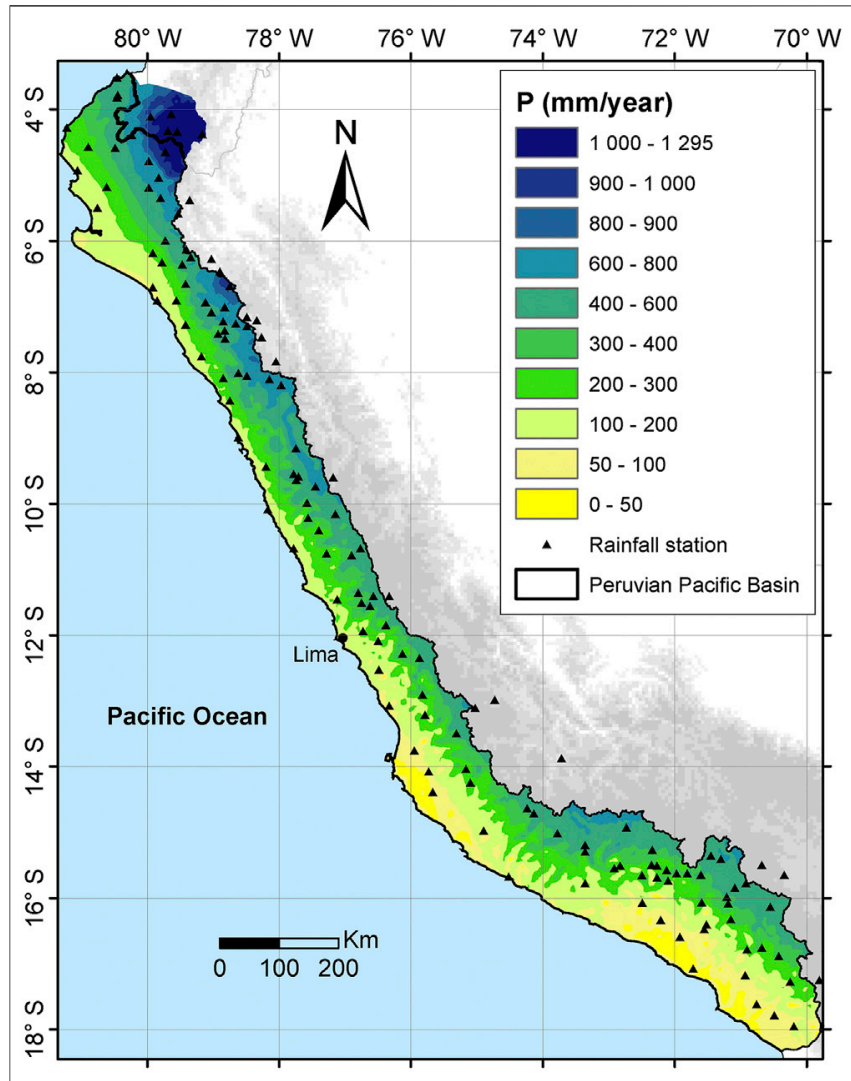

FIGURE 4 | Mean annual rainfall in the Pacific coast of Peru (1964-2011). Adapted from Rau et al. (2016).

Andes that can reach $190 \mathrm{~mm} / \mathrm{km}$ (Espinoza et al., 2015). Using 15 years of TRMM precipitation data and ground-based stations, Chavez and Takahashi (2017) propose a relationship between terrain elevation and mean surface precipitation, with a mean precipitation peak at an elevation of around 1,000 m.a.s.l. This peak can be explained by the vertical profile of the atmospheric moisture transport by the South American low-level jet (SALLJ). The rainfall-elevation relation from TRMM is similar to the one suggested by rain gauge observations. However, the TRMM measurements underestimates precipitation compared to observations (Espinoza et al., 2015; Chavez and Takahashi, 2017).

Wet episodes over this region are frequently related to large and medium MCS, with greater amount of wide convective and broad stratiform areas that can be triggered by the orographic lifting of the moist SALLJ (e.g., Giovannettone and Barros, 2009; Romatschke and Houze, 2013; Junquas et al., 2018; Kumar et al., 2019). Above surface elevations of 1,000 m.a.s.l, the largely stable dry-to-arid environment of the south tropical Andes limits the development and organization of the MCS (Mohr et al., 2014). Analyzing the triggering mechanisms of severe thunderstorms in the central Peruvian Andes (Mantaro Valley) during the 2015-2016 wet season, Flores-Rojas et al. (2019b) found that thunderstorms are associated with mesoscale convergence of atmospheric moisture flux generated by the intrusion of the sea-breeze from the Pacific Ocean, coupled with upper and middle westerly winds, and moisture advection from low-level winds at the east of the Andes. In addition, using observations from a vertically-pointed profile radar in the Mantaro basin, Kumar et al. (2020b) show that stratiform precipitation in the central Peruvian Andes is more common and lasts longer, but with low accumulated precipitation amounts.

\section{Orographic Effects on Frontal Precipitation Systems in the Subtropical and Extratropical Andes}

The orography of the Andes modifies frontal precipitation systems coming from the Pacific Ocean within the westerlies, as they move over the subtropical Andes (mostly in the winter), as well as in the extratropical Andes. Precipitation is mainly enhanced when the strong westerly (cross-barrier) winds associated with the Pacific fronts, are forced to ascent over the windward slopes of the Andes (Chile, e.g., Figure 5). Precipitation is then reduced when the westerly flow is forced to descend over the leeward slopes of the subtropical and extratropical Andes. The orographic precipitation enhancement has been estimated in several studies over the windward slopes of the Andes (Chile) using surface observations, as the ratio of mean annual precipitation in the upper part with respect to the lower part of the slopes. They have reported values of 1.51 along the Santiago Basin at $\sim 33.5^{\circ} \mathrm{S}$ (Falvey and Garreaud, 2007), 1.43 between $32.5^{\circ} \mathrm{S}$ and $37^{\circ} \mathrm{S}$ (Viale and Nuñez, 2011), 1.8 between $33^{\circ}$ and $44^{\circ} \mathrm{S}$ (Viale and Garreaud, 2015), and as a linear precipitation gradient over the terrain elevation of $6.3 \mathrm{~mm} / \mathrm{km}$ at $30^{\circ} \mathrm{S}$ (Scaff et al., 2017). Estimates of orographic precipitation reduction ratios range between 5 and 10, when comparing precipitation on the leeward slopes of the Andes to those in the windward slopes of the Andes (Viale and Nuñez, 2011; Viale et al., 2019).

Different studies and field experiments allowed for a better understanding of the physical processes associated with frontal systems moving over the Andes. The strong blocking effect of the high subtropical Andes (up to 6,000 m.a.s.l; Falvey and Garreaud, 2007; Barrett et al., 2011; Viale and Nuñez, 2011) can lead to a negative orographic precipitation gradient on the northern extend of the frontal system (Scaff et al., 2017). The low-level blocking effect can produce an enhancement of precipitation upstream of the barrier. This can happen through a strengthening of the frontal convergence zones and a modulation of the feederseeder mechanism in the pre-frontal and frontal environment (Barrett et al., 2009; Viale et al., 2013), changing the precipitation gradient upwind of the barrier. The thermodynamical processes and the dynamics of the blocking effect produced by the Andes on frontal systems still need to be better understood to further predict the amount and the spatial distribution of precipitation, especially over the extratropical Andes. The northerly flow associated with the blocking and the cyclonic circulation can transport large amounts of atmospheric moisture. This moisture transport can produce convective instability and a complex interaction with the flow aloft the mountain, resulting in convection (Bozkurt et al., 2016). Mesoscale processes affecting convective initiation in the interior of valleys embedded in frontal systems need to be studied in more detail, not only to explain 

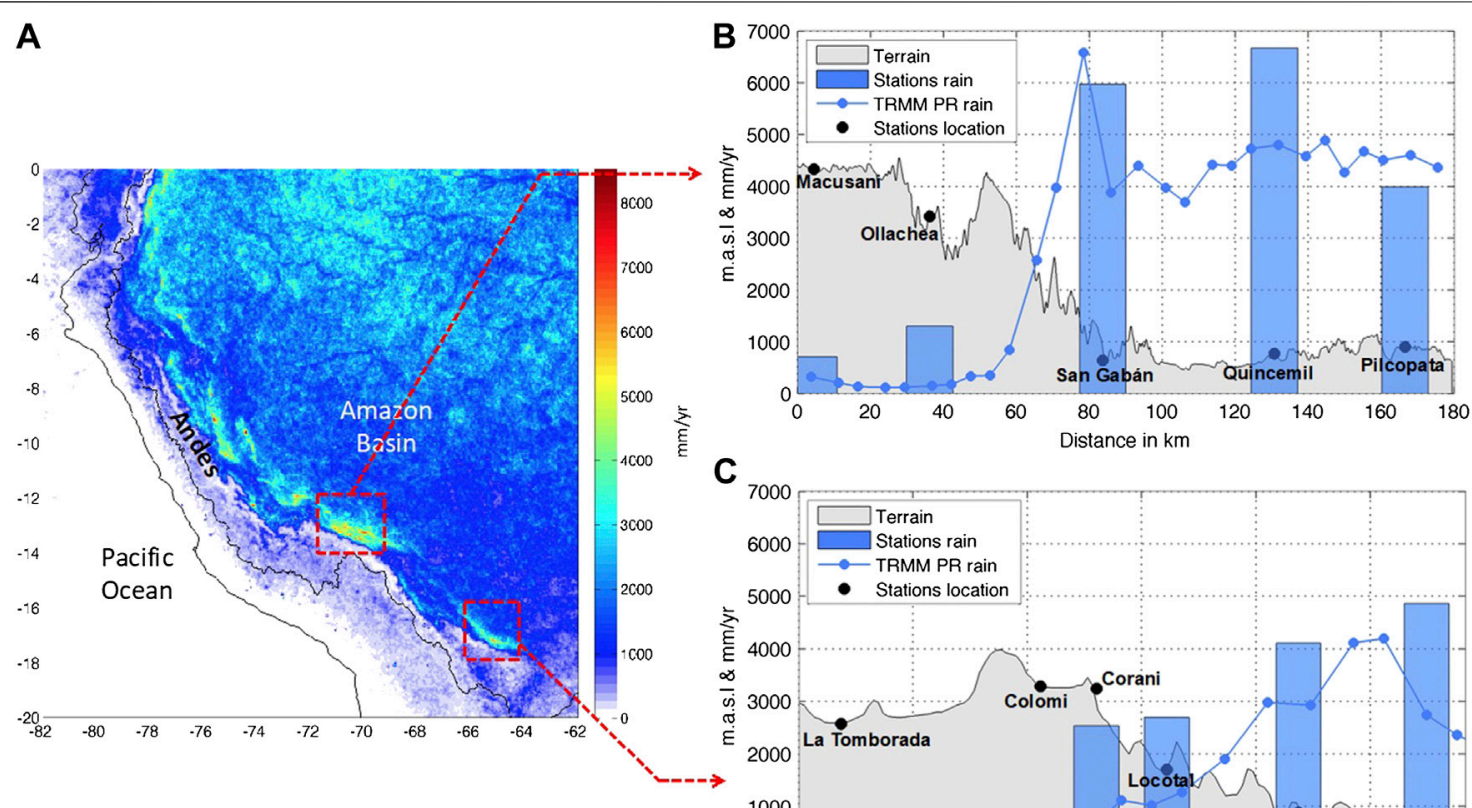

C

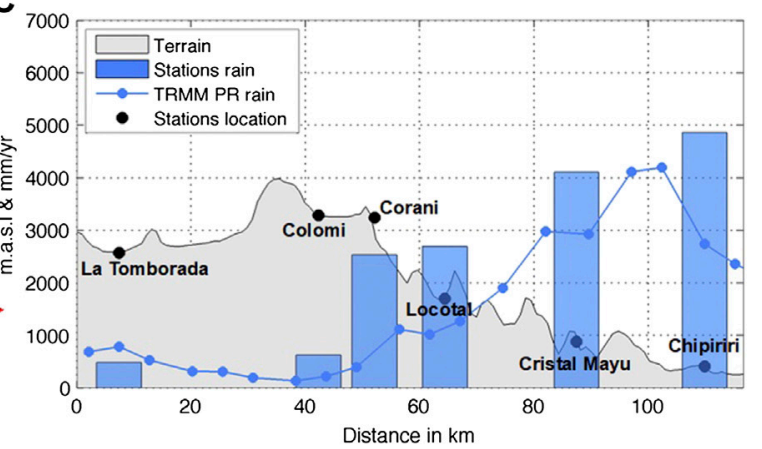

FIGURE 5 | (A) Mean annual rainfall in western tropical South America (mm/yr, 1998-2012) estimated using TRMM 2A25. (B) Topographical profile (gray) and total annual rainfall from Macusani to Pilcopata meteorological stations (Peru). The $x$-axis represents the horizontal distance and the $y$-axis the altitude (m.a.s.l) and the mean total rainfall (mm/yr) from observations (blue bars) and TRMM 2A25 (blue line). (C) As in (B) but for the La Tamborada-Chipiriri profile in Bolivia highlands. Adapted from Espinoza et al. (2015) @ W Water Resources Research. Reprinted by permission from John Wiley and Sons.

extreme precipitation events, but also to better describe postfrontal instabilities. At a monthly scale, a relatively linear regime characterizes the orographic effect in the Nahuelbuta coastal mountains at $37^{\circ} \mathrm{S}$ (Garreaud et al., 2016) and makes the rain shadow on the leeside more variable. Understanding the temporal and spatial variability of the main processes modulating the rain shadowing downhill remains a great scientific challenge.

Our knowledge of how the upstream flow and successive rainbands associated with a frontal system are affected by the Andes, is also incomplete (Viale et al., 2013; Garreaud et al., 2016). The characterization of the properties of the precipitating clouds moving over and adjacent to the Andes at mid-latitudes has shown significant differences in the along- and cross-barrier directions, suggesting different microphysical processes in orographic precipitation operating at different sectors of the Andes (Viale and Garreaud, 2015). The microphysical processes involved in the orographic enhancement have only been recently explored. A field experiment during 2015 provided a better understanding of the frequency of occurrence of cold or warm orographic rain over the Nahuelbuta coastal mountains, as well as the changes of drop size in function of the rain type (Massmann et al., 2017). The influence of maritime, continental and urban aerosols on the orographic precipitation over the coastal and the Andes Mountains has not been explored yet and needs to be addressed.

Summer precipitation has a minimum within the Andes at mid-latitudes, but the orographic effects are key in the summer convection initiation at their eastern foothills through diurnal thermally-driven mountain winds. Once convection is initiated on the foothills of the Andes, it develops into deep convective storms farther east in central Argentina (e.g., Zipser et al., 2006; Rasmussen and Houze 2011). The initiation and development of convection in this region is still under investigation and big efforts are now focused on field experiments. Two campaigns have been performed during the austral summer between 2018 and 2019: the Cloud, Aerosol, and Complex Terrain Interactions (CACTI), and the Remote sensing of Electrification, Lightning, And Mesoscale/microscale Processes with Adaptive Ground Observations (RELAMPAGO). These campaigns have been designed to provide a better understanding of the orographic effects of the Andes and the Sierras de Córdoba on the initiation, development and propagation of convection. The Andes Mountains also modulate the SALLJ and the atmospheric moisture transport that converges over the foothills. Besides diurnal thermally-driven mountain winds, other orographic mechanisms could be important to the initiation of convection, such as the presence of strong atmospheric moisture gradients (Ziegler and Rasmussen, 1998; Bechis et al., 2020), cold-pool gravity currents (Rotunno et al., 1988), the inertial-gravity waves (Li and Smith, 2010; Hierro et al., 2013), and the initiation of elevated convection due to other wave-types like bores (Geerts, 2017).

The lack of reliable measurements of solid precipitation in the Andes, at heights above 2000 m.a.s.l, has been an important 
drawback to many of the previous studies in the region (e.g., Falvey and Garreaud, 2007; Viale and Garreaud, 2015; Scaff et al., 2017; Condom et al., 2020). The uncertainty in the precipitation amount and phase is still proven to be a critical issue to properly characterize the observed and modeled distribution of precipitation over the Andes for seasonal water availability in agricultural activities, natural resources extraction, hydropower generation, and municipal consumption.

\section{HYDROCLIMATE VARIABILITY IN THE ANDES AT SUBSEASONAL, INTERANNUAL AND DECADAL TIMESCALES}

Hydroclimate variability in the Andes is modulated by different large-scale phenomena occurring within the Earth system at different timescales. Among them, El Niño-Southern Oscillation (ENSO), the Southern Annular Mode (SAM), and the variability of Atlantic sea surface temperatures (SST) impose distinctive interannual variability in the water cycle along the Andes. At longer timescales, the decadal and multidecadal modes of SST variability in the Pacific and Atlantic oceans, such as the Pacific Decadal Oscillation (PDO) and the Atlantic Multidecadal Oscillation (AMO), are among the main modulators of the Andean hydroclimate. At shorter timescales, the MaddenJulian Oscillation (MJO), the African easterly waves, and the high frequency variability of cross-equatorial low-level winds and the low-level jets are associated with the intraseasonal variability of different hydroclimatic variables in the Andes. Multiple studies have addressed the influence of these phenomena on the Andean hydroclimate. Recently, Cai et al. (2020) provide a review of the state of the art regarding the climatic impacts of ENSO in South America. Poveda et al. (2020) discuss the influence of ENSO on the occurrence of extreme hydrometeorological events along the Andes. This section reviews the main aspects of hydroclimate variability in the Andes related to ENSO and other phenomena influencing regional hydroclimate in the Andes at subseasonal, interannual and decadal timescales.

\section{Subseasonal Variability}

At subseasonal timescales, the MJO is among the main modulators of climate variability in the tropics (Madden and Julian, 1994). Over the north tropical Andes (north of $8^{\circ} \mathrm{S}$ ), the MJO is related to enhanced (reduced) amplitude of the diurnal cycle of precipitation during its westerly (easterly) phase (Poveda et al., 2005). Also, the MJO has been identified as a driver of extreme temperature and rainfall events in the south tropical Andes and the western Amazonia (Shimizu and Ambrizzi, 2016; Sulca et al., 2018; Grimm, 2019; Mayta et al., 2019; Recalde-Coronel et al., 2020). The occurrence of eastward-propagating equatorially confined MJO events that do not evolve through a complete life cycle are associated with suppressed rainfall conditions over the tropical Andes (Mayta et al., 2019; Recalde-Coronel et al., 2020). Moreover, in the Andes-Amazon transition region, the MJO convection modulates the basic response of ENSO on extreme precipitation events in this region, favoring dry (wet) extreme events when the MJO convection over Indonesia is enhanced (suppressed)
(Shimizu and Ambrizzi, 2016; Shimizu et al., 2016). The interactions between ENSO and MJO are of particular relevance since precipitation and temperature anomalies observed in the south tropical Andes during the different ENSO phases, without the simultaneous occurrence of the MJO, are modified during events when ENSO and MJO occur simultaneously (Shimizu and Ambrizzi, 2016).

Over the south tropical Andes (between $8^{\circ} \mathrm{S}$ and $27^{\circ} \mathrm{S}$ ), incursions of low-level southern winds from southern South America are related to the variability of the cloud cover in the Cordillera Real in Bolivia (Sicart et al., 2016). In addition, southerly incursions of cold and dry air along the eastern the Andes, low cloud cover, surface specific humidity, and soil moisture are key factors controlling the day-to-day variability of minimal temperature in the central Peruvian Andes (Saavedra and Takahashi, 2017; Sulca et al., 2018). During the austral summer, subseasonal rainfall variability over south tropical Andes is in part related to the variability of the South Atlantic Convergence Zone (SACZ) and the Bolivian High-Nordeste Low system, as discussed in Espinoza et al. (2020) and Jones and Carvalho (2002). Dry and wet spells in the Peruvian Andes show a dipole pattern with precipitation anomalies of the opposite sign over northeastern Brazil, which is related to large-scale changes in the upper-troposphere circulation over the Bolivian high-Nordeste low system, in association with northwardpropagating extratropical Rossby wave trains (Sulca et al., 2016). The active easterly winds at upper troposphere related to the Bolivian High enhance moisture flux from the lowland Amazon, which favors wet conditions in the tropical Andes (Garreaud et al., 2003; Sulca et al., 2016; Chavez and Takahashi, 2017; Junquas et al., 2018). On the eastern flank of the south tropical Andes (Peru and Bolivia) and in regions below 2000 m.a.s.l, intraseasonal rainfall variability has been related to the southerly low-level winds regime (Wang and $\mathrm{Fu}, 2002$ ) and to the intensification of the low-level circulation (Espinoza et al., 2015; Chavez and Takahashi, 2017; Paccini et al., 2017).

Outside the tropical band, the effect of the MJO upon precipitation is less clear and mediated by Rossby wave activity propagating across the South Pacific. Yet, recent studies have shown that rainfall in northern and central Chile tends to increase during active MJO phases near the central equatorial Pacific (Barrett et al., 2012; Juliá et al., 2012). These findings support studies that speculated the Pacific South American (PSA) teleconnection mode (Mo and Higgins, 1998; Grimm and Ambrizzi, 2009) was activated when deep convection moved from the maritime continent into the central Pacific region, where most precipitation concentrates to the south of the equator. The role of the MJO in setting the stage for episodes of heavy precipitation along the subtropical Andes was particularly evident in late March 2015, when the MJO reached its largest amplitude on record. Linked to that activity, a strong blocking anticyclone, sited in the Bellingshausen Sea, caused extreme high SSTs in southwestern South America and the Antarctic Peninsula (Rondanelli et al., 2019). At the same time, a cut-off low crossed over northern Chile causing copious rain in the otherwise hyper arid Atacama Desert and subtropical Andes, resulting in flashflood that caused more than 60 fatalities 


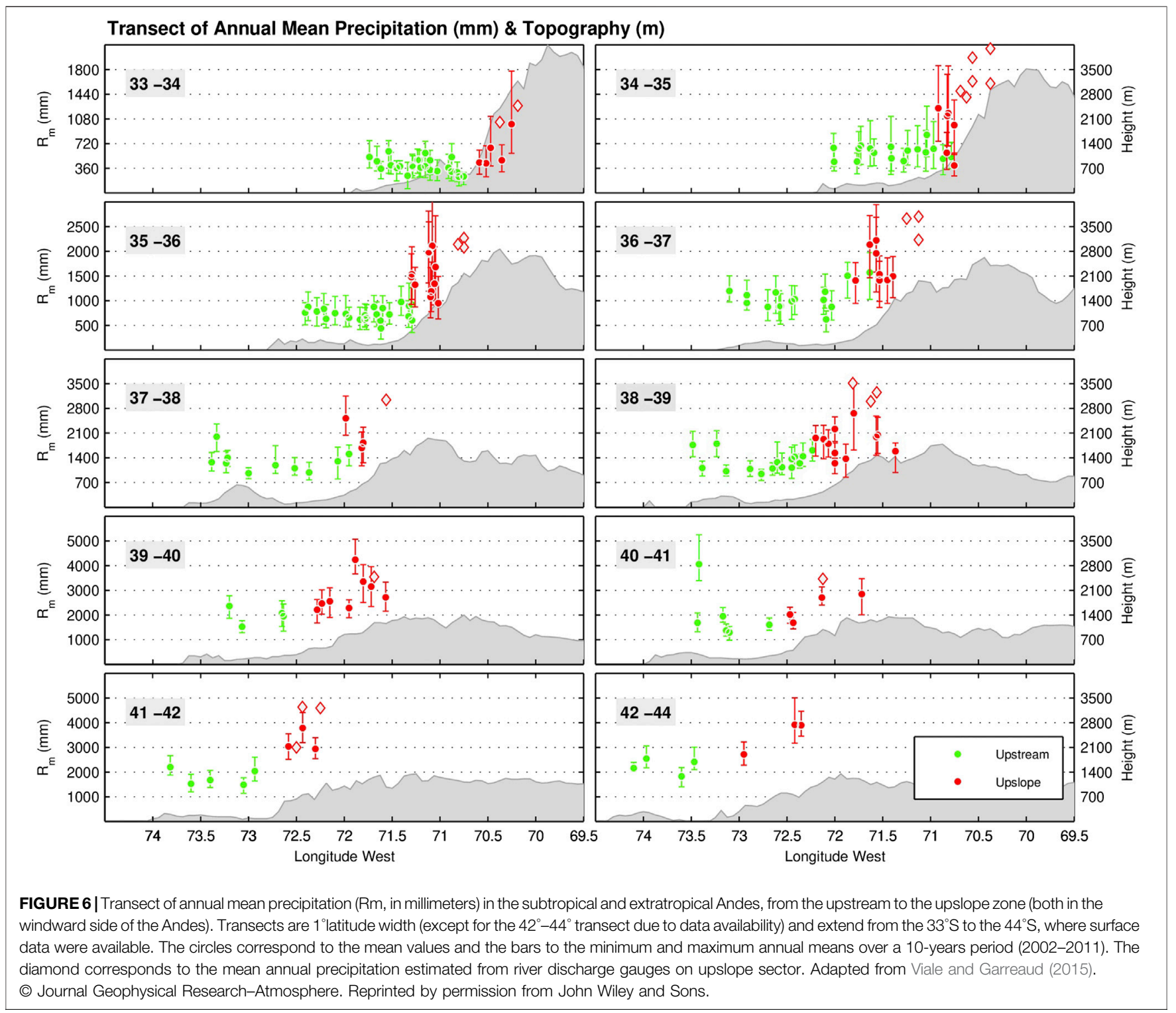

and severe damage in infrastructure (Kreft et al., 2016; Rondanelli et al., 2019). To our best knowledge, no studies have been conducted relating the MJO to rainfall variability in the extratropical Andes, but rainfall episodes do exhibit some clustering during periods of blocking in high latitudes with intrinsic subseasonal periodicity (Rutllant and Fuenzalida, 1991).

\section{Interannual Variability}

Interannual climate variability in the Andes is strongly modulated by ENSO. For instance, over the north tropical Andes (mainly Colombia and Venezuela), warm ENSO events (El Niño) are associated with reduced diurnal, seasonal and annual precipitation, while cold ENSO events (La Niña) are related with increased precipitation, runoff and soil moisture (e.g., Poveda et al., 2005; Poveda et al., 2006; Poveda et al., 2011; Bedoya-Soto et al., 2018). The largest ENSO influence in the region is observed during December-January-February (DJF), although such influence is stronger (weaker) over the northwestern (northeastern) Andes (Poveda et al., 2011; Navarro-Monterroza et al., 2019). The impact of ENSO on the Colombian Andes relates to weaker (stronger) SST and surface pressure gradients between the coast of Peru and Ecuador and the Colombian Pacific (Poveda et al., 2006; Cai et al., 2020) that induces a weaker (stronger) atmospheric moisture transport to the region during El Niño (La Niña) (Hoyos et al., 2017; Sierra et al., 2018; Morales et al., 2020). However, the diversity of ENSO events also implies a wide range of atmospheric teleconnections worldwide (e.g., Larkin and Harrison, 2005; Ashok et al., 2007; Sun et al., 2015; Tedeschi et al., 2013). In the north tropical Andes, mainly Colombia, Canonical El Niño events, that are characterized by positive SST anomalies located over the tropical eastern Pacific, are associated with largest reductions of precipitation in the region, compared to El Niño Modoki events, that are characterized by positive SST anomalies located 

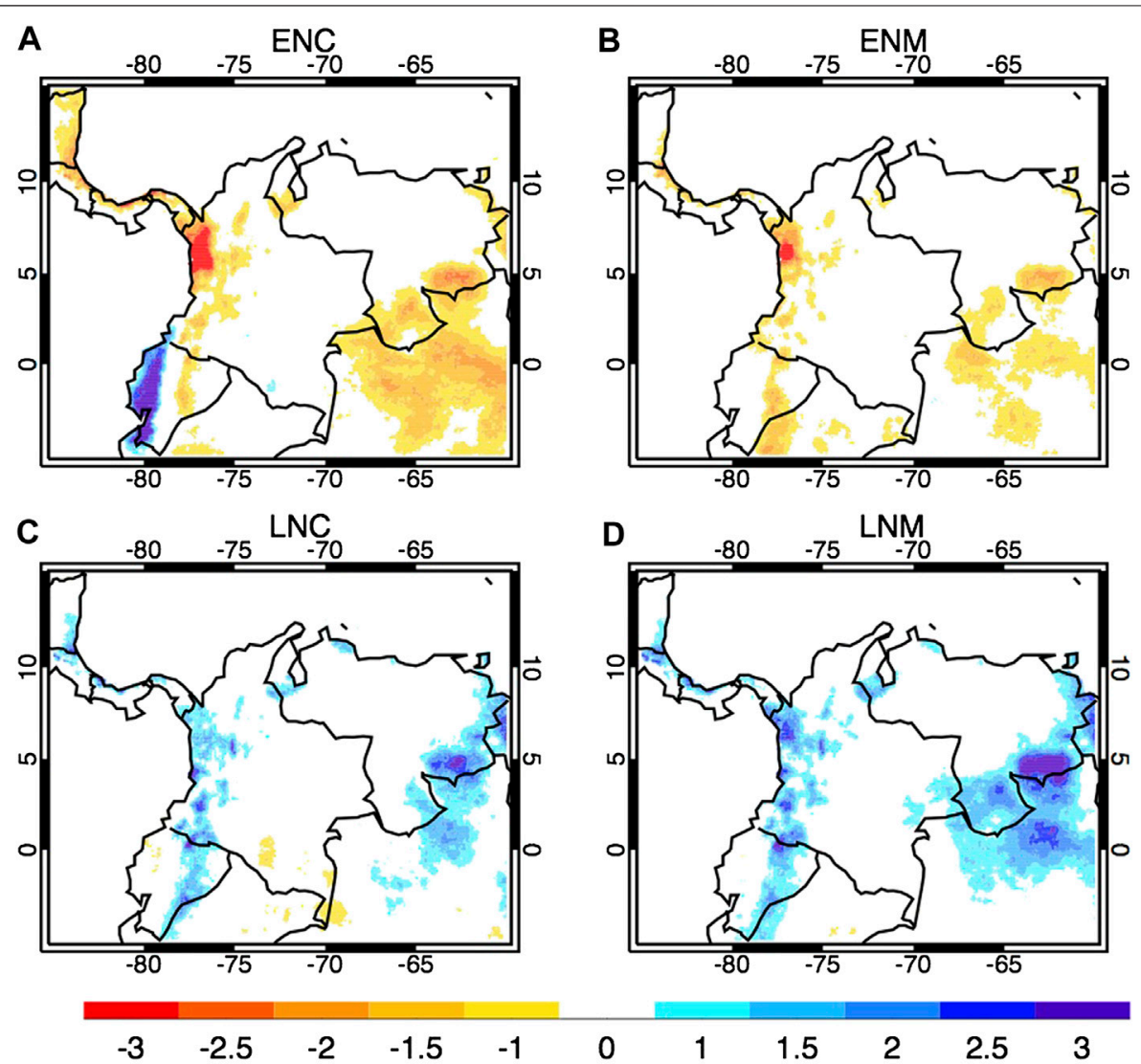

Precipitation Anomalies [mm/day]

FIGURE 7 | Precipitation anomalies in the north tropical Andes during (A) Canonical El Niño (ENC), (B) El Niño Modoki (ENM), (C) Canonical La Niña (LNC), and (D) La Niña Modoki (LNM) for DJF according to CHIRPS data. ENSO years are considered according to Navarro-Monterroza et al. (2019) for the period $1981-2015$.

over the tropical central Pacific (Navarro-Monterroza et al., 2019; Figure 6). However, the increases of precipitation over the north tropical Andes during La Niña Modoki events are larger than those observed during Canonical La Niña episodes (NavarroMonterroza et al., 2019). This influence in precipitation is in part associated with changes in the Caribbean and the Choco low-level jets (see Espinoza et al., 2020; Poveda and Mesa, 2000; Serna et al., 2018; Sierra et al., 2018).

Although ENSO dominates interannual climate variability in the north tropical Andes, it is not the only source of interannual variability in the region. The interannual variability of SSTs over the tropical north Atlantic (TNA) also has influence on the regional hydroclimatology The TNA is the main source of atmospheric moisture for the north tropical Andes (Sakamoto et al., 2011; Arias et al., 2015; Hoyos et al., 2017). In particular, a warmer TNA is associated with enhanced precipitation in Colombia and Venezuela, as well as with a weaker Caribbean low-level jet, which favors atmospheric water vapor transport toward northern South America (Arias et al., 2015; Arias et al., 2020). Farther south, precipitation variability over the eastern Andes of Ecuador relates to a dipole-like correlation pattern in the north tropical Atlantic (Vuille et al., 1999). Moreover, to the east of the Paute river in Ecuador, within the south tropical Andes, the variability of MCSs is positively correlated to the south tropical Atlantic SST anomalies, due to the variability of the South Atlantic subtropical high, exhibiting departures from this relationship when ENSO-related anomalies occur in the tropical Pacific (Campozano et al., 2018). In the western side of the Andes in Ecuador and northern Peru, El Niño events are associated with intense convective activity related to warm SST conditions in the eastern equatorial Pacific (e.g., Recalde-Coronel, 2014; Takahashi and Martínez, 2017; Figure 7). In this region, El Niño is the main modulator of interannual hydrological variability and catastrophic floods have been associated with this phenomenon (see Takahashi and Martínez (2017), Poveda et al. (2020), and Cai et al. (2020) for more details).

Regarding ENSO effects over the south tropical Andes, different studies document negative (positive) rainfall anomalies over the Peruvian Andes during El Niño (La Niña) (e.g., Lagos et al., 2008; Espinoza et al., 2011; Lavado and Espinoza, 2014; Sulca et al., 2016; Figure 8). In Peru, different studies have analyzed the different rainfall impacts associated with Canonical and Modoki El Niño events, synthetized by the eastern Pacific (E) and central Pacific (C) El Niño indices, 

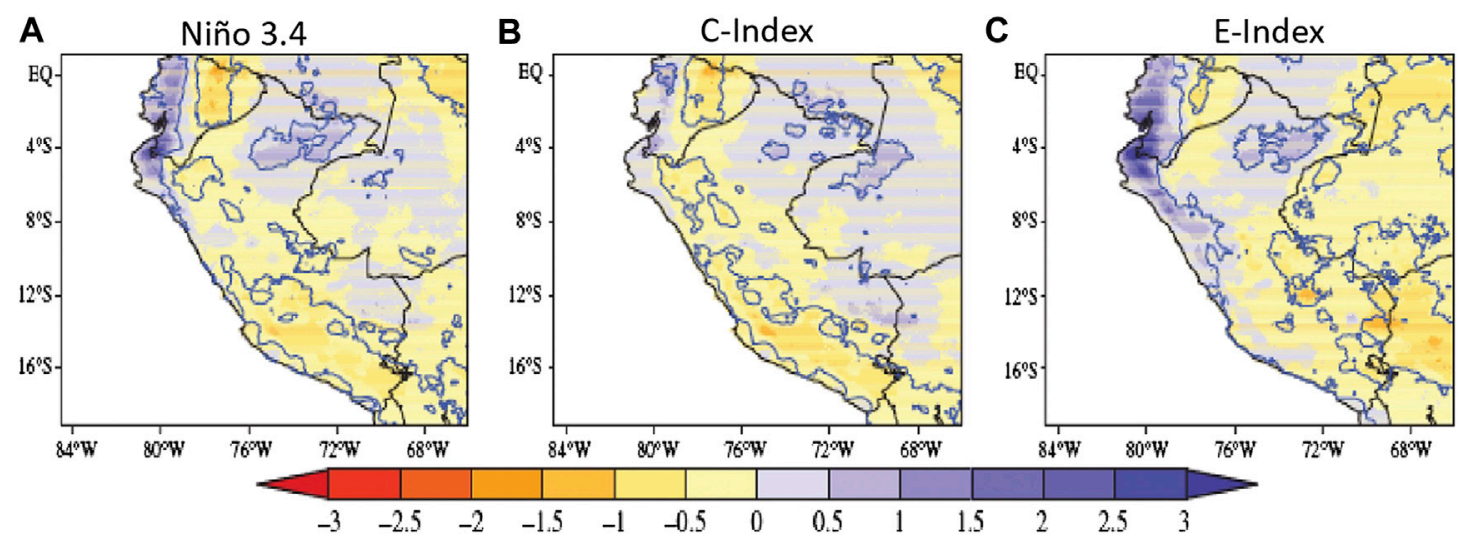

FIGURE 8 | Linear regression coefficients between ENSO indices (Niño 3.4, C-El Niño Modoki, and E-Canonical El Niño) and PISCO precipitation data (A-C, respectively) in the south tropical Andes. Values are in mm day- 1 for one standard deviation of each corresponding ENSO index. Blue (Red) shading represents positive (negative) precipitation anomalies in intervals of $0.5(-0.5) \mathrm{mm}$ day -1 per standard deviation. Black contour represents the climatological isoline of $4 \mathrm{~mm}$ day-1. Blue contours represent significant correlation between ENSO indices and precipitation at the 95\% confidence level. Analysis based on the period 1980-2016. Adapted from Sulca et al. (2017). ( I International Journal of Climatology. Reprinted by permission from John Wiley and Sons.

respectively (Takahashi et al., 2011). Enhanced coastal and reduced Andean/Amazonian rainfall is associated with surface warming in the eastern (Canonical El Niño) and central equatorial Pacific (El Niño Modoki), respectively (Figure 7). Both anomalies can occur, with varying relative magnitudes, during El Niño or (with the opposite sign) during La Niña (Lagos et al., 2008; Lavado-Casimiro et al., 2013; Lavado and Espinoza, 2014; Rau et al., 2016; Sulca et al., 2017; Imfeld et al., 2019; Segura et al., 2019). Both Canonical El Niño and El Niño Modoki events are associated with a weakened upper-level easterly flow over Peru, but they are more restricted to the central and southern Peruvian Andes (Sulca et al., 2017).

A weak (strong) and northward (southward) displacement of the Bolivian High is associated with westerly (easterly) anomalies at $200 \mathrm{hPa}$ over the south tropical Andes, which inhibits (enhances) atmospheric moisture influx from the east, thereby increasing (reducing) atmospheric stability and reducing (increasing) precipitation over upper-elevation regions of the Andes (Garreaud, 1999; Garreaud et al., 2003; Vuille and Keimig, 2004; Neukom et al., 2015). Segura et al. (2019) detected a relationship between precipitation at higher elevations in the Andes north of $10^{\circ} \mathrm{S}$ and easterly winds at $200 \mathrm{hPa}$ during February-April. In addition, westerly (easterly) anomalies at $200 \mathrm{hPa}$ over the south tropical Andes are strongly associated with warm (cold) SST anomalies in the central Pacific (see updated studies from Sulca et al., 2017; Segura et al., 2019; Imfeld et al., 2019). In fact, over the Altiplano, a dominant negative (positive) relationship of summer (DJF) rainfall with El Niño (La Niña) events has been identified (Garreaud et al., 2003; Vuille et al., 2008; Huerta and Lavado-Casimiro, 2020). This signal becomes rather weak to the north of the Altiplano and to the sub-Andean valleys of the southwestern Amazon below 1,500 m.a.s.l (Ronchail and Gallaire, 2006). During the drier austral winter, negative relationships with the TNA SST appear for the eastern Andean foothills and adjacent southwestern Amazonian lowlands (Espinoza et al., 2011;

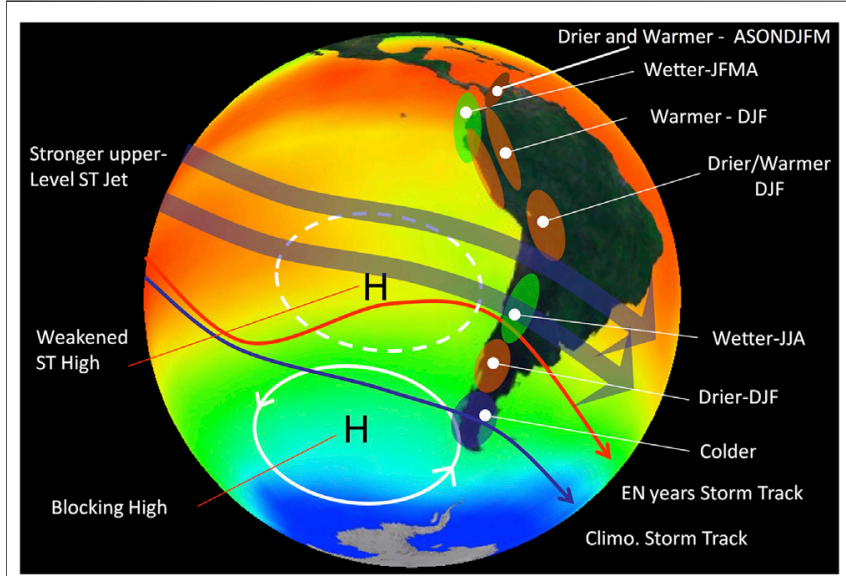

FIGURE 9 | Schematics of the El Niño impacts in precipitation over the Andes. Climate alterations during La Niña events are roughly opposite. "DJF" corresponds to the December-January season, "JJA" to June-August, "JFMA" to January-April, and "ASONDJFM" to August-March. "EN" denotes El Niño while "ST" denotes subtropical.

Marengo and Espinoza, 2016; Molina-Carpio et al., 2017), which are not always mediated by ENSO.

Segura et al. (2019) show that extreme monthly wet events in the northern Peruvian Andes are related to convection over the equatorial Amazon during February-April period, showing an atmospheric relationship between the Amazon and the Andes (Figure 9). Extreme monthly dry events over the Equatorial Andes (north of $8^{\circ} \mathrm{S}$ ) during the February-April period are related to a strengthened Walker Cell, especially in the eastern Pacific. The extreme wet (dry) events over this region are associated with an anomalous southward (northward) displaced eastern Pacific ITCZ.

The influence of ENSO on climate variability in centralsouthern Chile, thus affecting part of the subtropical Andes $\left(27^{\circ} \mathrm{S}-37^{\circ} \mathrm{S}\right)$, has been known for a long time. Many studies 

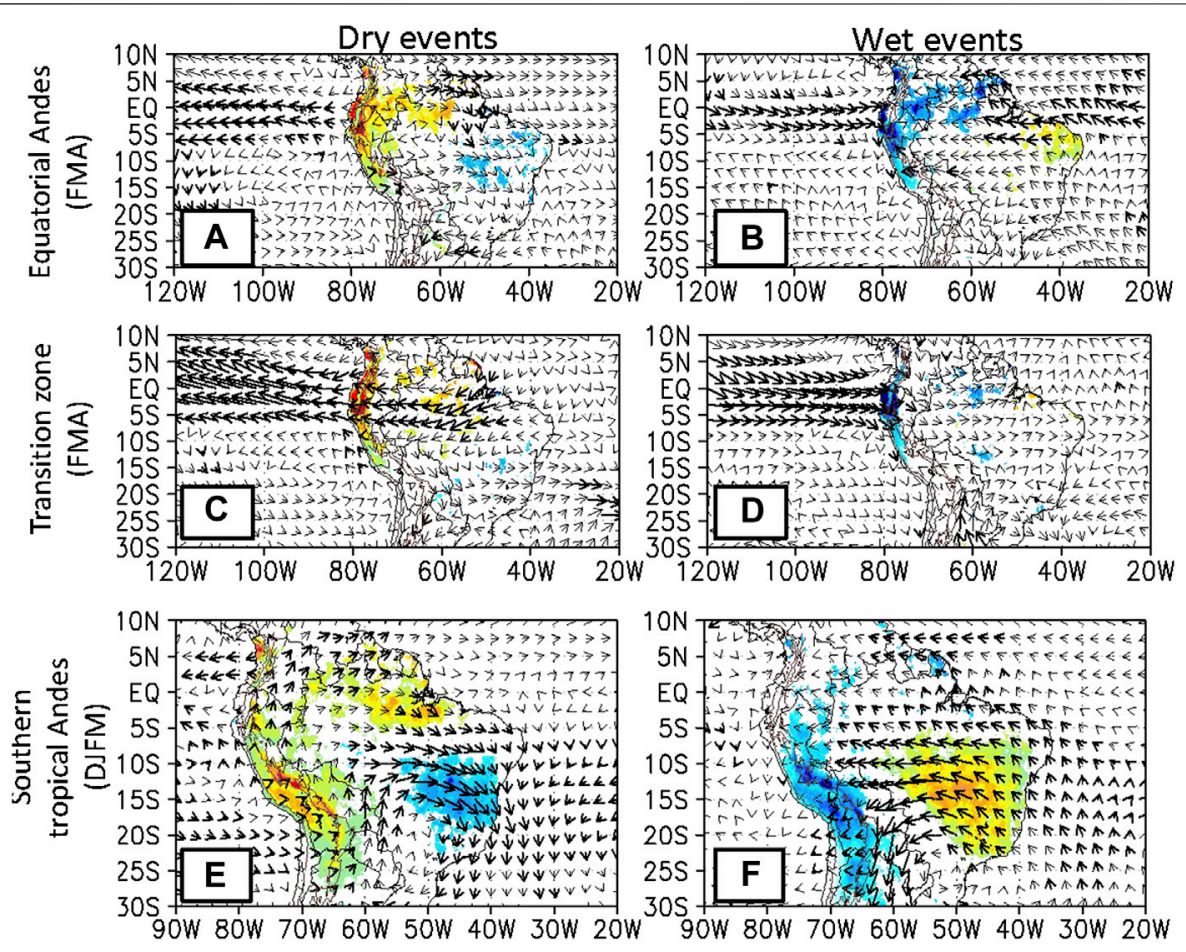

FIGURE 10 | (A) Composite for CHIRPS precipitation (shaded; $p<0.05$ according to a Cramér test) and vertically integrated water vapor flux (vectors) using a Kramer test with a p-value of 0.05. (B) Similar to (A) but for wet events in the northern Peruvian Andes from February to april. (C,D) Similar to $(\mathbf{A}, \mathbf{B})$, respectively, but for dry and wet events in the transition zone from February to april. (E) Anomalies considering monthly dry events from February to april in the equatorial Andes. Only significant precipitation anomalies are shown and bold vectors represent significant meridional or zonal vertically integrated water vapor flux anomalies. (F) similar to (A,B), respectively, but for dry and wet events in the south tropical Andes from December to March. Adapted from Segura et al. (2019). () Climate Dynamics. Reprinted by permission from Springer Nature.

have confirmed the existence of a warm-wet/cold-dry relation between rainfall in central Chile and SST anomalies in the tropical Pacific related to ENSO (Figure 8) (e.g., Rubin 1955; Pittock 1980; Quinn and Neal 1983; Aceituno 1988; Montecinos et al., 2000; Montecinos and Aceituno 2003). The interannual variability of rainfall at lower elevations over central Chile is tightly coupled with the snowfall accumulation over the Andes immediately to the east of this region (e.g., Garreaud et al., 2017; González-Reyes et al., 2017).

Rutllant and Fuenzalida (1991) gave an initial discussion of the physical mechanisms behind the aforementioned relationship. Their synoptic analysis found that major winter storms in central Chile during El Niño episodes are related to persistent anticyclonic anomalies (i.e., blocking conditions) over the Amundsen Bellingshausen Seas (ABS) to the west of the Antarctic Peninsula. Blocking over the ABS is not infrequent (Renwick and Revell, 1999) and often associated with wave trains triggered by atmospheric heating in the tropical Pacific in what is known as the Pacific-South American (PSA) teleconnection pattern. Frequent ABS blocking in conjunction with the widespread weakening of the PSA during El Niño years leads to a equatorward displacement of the storm track (Solman and Menéndez, 2002) and hence more precipitation in central Chile and the adjacent cordillera $\left(30^{\circ} \mathrm{S}-35^{\circ} \mathrm{S}\right)$. A stronger subtropical jet stream and enhanced atmospheric moisture availability over the southeastern Pacific during El Niño years may also contribute to the rainfall and snowfall surplus (Montecinos and Aceituno, 2003). Approximately, the opposite large-scale configuration takes place during La Niña years. Enhanced cyclonic activity over the ABS, stronger PSA and weaker mid-level westerlies produce rainfall deficit in central Chile during the cold phase of ENSO.

Farther south, between $38^{\circ} \mathrm{S}$ and $45^{\circ} \mathrm{S}$, ENSO-related precipitation anomalies are still marked, but they occur in summer, when El Niño (La Niña) years often bring less (more) precipitation than normal over western Patagonia and the adjacent sectors of the Austral Andes (Montecinos and Aceituno, 2003; Garreaud, 2018). Farther south, the impact of ENSO begins to fade at the same time that modulation by the SAM becomes more prominent. Indeed, SAM has a significant correlation with rainfall (and possibly snowfall) such that its positive polarity leads to precipitation deficit across much of the southernmost part of the Andes cordillera (Gillett et al., 2006; Garreaud et al., 2009; Silvestri and Vera, 2009). Historically, the influence of SAM and ENSO on precipitation over the austral Andes has counteracted each other. Nonetheless, there are some years in which both effects can couple, as during the summer of 2016, when a strong El Niño event and a positive phase of SAM were conducive to one of the worst droughts over western Patagonia and the adjacent Andes (Figure 10 and Figure 11), with dramatic environmental impacts (Garreaud, 2018). 

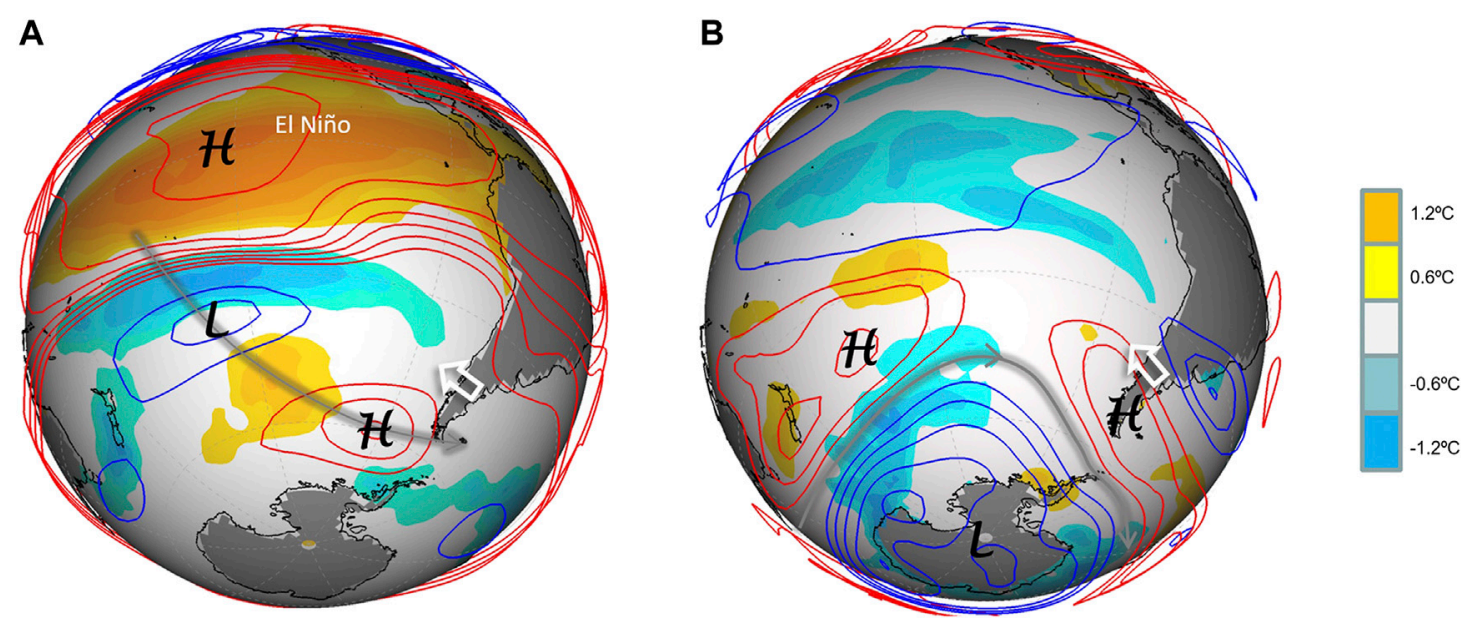

FIGURE 11 | (A) Sea surface temperature anomalies (shaded) and $200 \mathrm{hPa}$ geopotential height anomalies (contoured every $25 \mathrm{~m}$ : positive in red, negative in blue contours) during El Niño austral summer (Dec-Feb). (B) As (A) but for summers with the Southern Annular Mode (SAM) in its positive phase (SAM Index >1). Note how both modes produce easterly wind anomalies over the Austral Andes (white arrow) conducive to dry conditions in the otherwise hyper humid western Patagonia.

\section{Decadal Variability}

Despite the lack of long-term measurements of hydroclimatic variables in the Andes (Condom et al., 2020), different studies have studied the decadal and multidecadal variability of Andean hydroclimate. For instance, Kayano and Capistrano (2014) indicate that the cold (warm) phase of AMO strengthens El Niño (La Niña) events due to the presence of a negative inter-Pacific-Atlantic SSTs. Kayano et al. (2019) found that the low-frequency anomalous SST cooling (warming) of the tropical Pacific during the PDO cold phase (warm phase) favors (inhibits) the settling of the La Niña-related negative SST anomalies in the tropical Pacific. Moreover, La Niña events are favored during the simultaneous occurrence of the AMO warm phase and the PDO cold phase (Kayano et al., 2019). From the mid-1970s to late 1990s, a positive phase of the PDO was related with more frequent strong central Pacific La Niña and strong eastern Pacific El Niño events, including the 1982-83 and 1997-98 Superniños (Cai et al., 2020). Afterward, the negative phase of the PDO features more central Pacific El Niño events (El Niño Modoki), which are smaller in amplitude. This modulation of decadal modes of variability on ENSO in turn modulates the teleconnections with rainfall in northern South America, including the Andes.

Over the north tropical Andes, the PDO and AMO influence precipitation due to alterations of the Caribbean and Choco lowlevel jets (Loaiza Cerón et al., 2020). In particular, the occurrence of cold SST anomalies in the Pacific during the occurrence of the AMO warm phase observed during 1998-2016 strengthened (weakened) the Choco (Caribbean) low-level jet, increasing atmospheric moisture transport and precipitation in the north tropical Andes. Moreover, the strengthening of the Choco jet observed after 1997 is found to be partially related to the occurrence of La Niña events during the simultaneous occurrence of a PDO cold phase and an AMO warm phase (Loaiza Cerón et al., 2020).
Decadal variations in rainfall in the Ecuadorian Andes have been detected. Mora and Willems (2012) show the occurrence of positive precipitation anomalies during 1969-1974 in the Paute river basin, within the lowlands of the Ecuadorian Andes, while the opposite is observed during 1983-1986. Also, in the high paramo regions of the Ecuadorian Andes, increased (reduced) rainfall is observed during 1978-1981 (1965-1974) (Mora and Willems, 2012). Along the Peruvian Pacific coast, fluctuations in the ENSO - rainfall relationship has been identified at decadal timescales considering the 1964-2011 period (Bourrel et al., 2015). The authors show shifts in this relationship in the 1970 s and the 2000 s, over which main ENSO characteristics significantly changed (e.g., Canonical and Modoki modes).

Silva et al. (2008), Marengo (2009), Espinoza et al. (2009b), and Lavado-Casimiro et al. (2012) identified that multidecadal variations of rainfall in the western Amazon/eastern tropical Andes might be linked to SSTs in the subtropical Atlantic. The AMO affects hydroclimate in this region through alterations of the SALLJ, with active SALLJ days during negative AMO phases in association with negative precipitation anomalies over the Andes-Amazon transition region and the Atlantic ITCZ (Jones and Carvalho, 2018). More recently, Campozano et al. (2020) highlight that PDO modulates the ENSO influence on precipitation in the eastern Ecuadorian Andes, where the PDO warm phase enhances (reduces) precipitation when in phase with El Niño (La Niña). Furthermore, the PDO warm phase influences the connection between ENSO Canonical events and precipitation in the eastern Ecuadorian Andes while this link is not affected for the ENSO Modoki events (Campozano et al., 2020). Over the northern Altiplano, Segura et al. (2016) documented a significant decadal variability on hydroclimate variables (including the water levels of the Titicaca lake). These authors show that this decadal variability is related to low frequency variability of both the western Pacific 
SSTa and the zonal wind at $200 \mathrm{hPa}$ above the Central Andes. In the northern Altiplano and the southern Peruvian Andes, a slightly increase in summer precipitation has been recently identified (Imfeld et al., 2020; Segura et al., 2020), associated with an enhanced upward atmospheric moisture from the western Amazon (Espinoza et al., 2019). This change in the atmospheric circulation has been related to warming conditions over the north tropical Atlantic SST during the last two decades (Segura et al., 2020).

The same signal documented for the northern Altiplano is detected for the precipitation in the humid valleys (Yugas) between 1,000 and 4,000 m.a.s.l in the eastern Andean slopes in Bolivia (Ronchail and Gallaire, 2006; Molina-Carpio et al., 2019). Decadal variability identified by Segura et al. (2016) shows a very significant negative correlation with the low frequency variability of the central Pacific ENSO, particularly with the SSTs in the Niño four region (Stuecker, 2018). The results of Seiler et al. (2013) suggest that, in relation to the northern Altiplano, the southwestern Altiplano exhibits a decadal variability of opposite sign. Decadal precipitation variability during the drier winter season (JJA) has been identified in the eastern Altiplano, the eastern Andean foothills below 1,000 m.a.s.l and the adjacent southwestern Amazonian lowlands. This variability has been associated with the TNA SST, as for the interannual variability (Espinoza et al., 2011; Molina-Carpio et al., 2017; Espinoza et al., 2019). Several authors, as cited by Stuecker (2018), relate both interannual and decadal tropical north Atlantic with central Pacific SST variability.

Along the subtropical and part of the extratropical Andes, rainfall also exhibits low frequency phenomena, particularly related to the PDO. Given the ENSO-like structure of the teleconnections in the southern hemisphere (Garreaud, 1999), its cold (warm) phase tends to produce drier (wetter) periods with respect to long term mean (Garreaud et al., 2009; Masiokas et al., 2010; Muñoz et al., 2016; González-Reyes et al., 2017). The statistical relationship between PDO and rainfall in central Chile is modest $(r \approx$ 0.4 ) but such analysis is based on only a few PDO multi-year blocks during the 20th century (Garreaud et al., 2020). In any case, the positive phase of the PDO initiated after the shift in the mid-1970s (Jacques-Coper and Garreaud, 2014) seems partially responsible for the rainy conditions in this region in the 1980's and 1990's. Since then, the PDO has been trending toward its negative polarity thus contributing to the drying trend observed in the extratropical Andes between 30 and $40^{\circ} \mathrm{S}$ (Boisier et al., 2016) and the maintenance of the central Chile megadrought since 2010 (Garreaud et al., 2020). The positive phase of the PDO also seems to produce a slight warming in the Andes to the south of $40^{\circ} \mathrm{S}$ (Garreaud et al., 2009; Jacques-Coper and Garreaud, 2014), presumably in connection with the excessive insolation when anticyclonic conditions prevail over the Patagonia. For a further discussion of hydroclimate variability in the Andes on longer timescales, Pabón-Caicedo et al. (2020) discussed the hydroclimate variability over the entire Andes throughout the last two millennia, including multidecadal changes.

\section{SUMMARY AND OPEN RESEARCH QUESTIONS}

Due to its long latitudinal extension and its prominent topography, a large variety of mountain climates are documented in the Andes Cordillera. These climates vary strongly across and along the approximately $7,240 \mathrm{~km}$ of the range: from northern South America to southern Patagonia and Tierra del Fuego, crossing seven countries (Venezuela, Colombia, Ecuador, Peru, Bolivia, Chile and Argentina). Due to climate change and the growing human population in this region (more than 80 million people), the exposure of the Andean societies to disasters from hydrometeorological extremes is frequently discussed in the scientific literature. Poveda et al. (2020) provided a comprehensive review of the main high impact events associated with hydroclimate variability in the Andes.

Changes in the regional hydrological cycle brought about from climate variability, climate change and land use changes are of particular importance because of their impacts on human and ecological systems. The Andes exhibits a large variety of hydrological regimes (Figure 1), which are partially influenced by large and regional-scale climatological conditions, as discussed in Part I of this two-part review (Espinoza et al., 2020). For instance, annual cycles of river discharge in the north tropical Andes (north of $8^{\circ} \mathrm{S}$ ) exhibit unimodal or bimodal regimes, depending on the annual cycle of precipitation, the dynamics of atmospheric low-level jets and the land surface-atmosphere interactions. Rivers of the inner Andes of Colombia have a bimodal discharge annual cycle whereas rivers draining into the Caribbean, Orinoco and Amazon basins exhibit a unimodal annual regime. In the northern Peruvian and Ecuadorian Amazon, the hydrological seasonality is more complex (e.g., bimodal or unimodal) due to the influence of several rainfall regimes. Rivers of the equatorial Andes of the Pacific drainage have a unimodal discharge annual cycle, with a peak in March-April in association with southerly position of the ITCZ. Therefore, it is relevant to understand the physical processes involved in the bimodal rainfall annual cycle, restricted on the north tropical and equatorial Andes, while unimodal cycles are observed southward in the tropical Andes.

Rivers in the south tropical Andes (between $8^{\circ} \mathrm{S}$ and $27^{\circ} \mathrm{S}$ ) are characterized by discharge peaks during February and March, associated with the wet season in the mature phase of the South American Monsoon system. Between the southern end of the Altiplano $\left(27^{\circ} \mathrm{S}\right)$ and about $35^{\circ} \mathrm{S}$, most rivers also show a unimodal annual cycle characterized by an austral summer discharge peak, but in this case largely related to the melting of the winter snow accumulated in the upper basins. Some rivers in this region also receive important contributions from glaciers and permanent icerich permafrost features such as rock glaciers. Further south in the extratropical Andes (south of $37^{\circ} \mathrm{S}$ ), some sectors show a single discharge peak due to higher precipitation during austral winter, while others also show a secondary peak in spring-early austral summer due to snowmelt. Only a few river basins with large glaciated areas (such as those draining the north and south Patagonian Icefields) show a discernible glacier melt signal on 
river flows. Masiokas et al. (2020) presented a detailed discussion on recent changes in the Andean cryosphere.

Despite the clear identification of the different regional patterns of runoff cycles in the Andes, there are still gaps limiting a complete understanding of runoff variability in the region. Particularly, further research is required to explain the role of precipitation recycling, soil moisture, evapotranspiration, vegetation, groundwater and aquifers, as well as glaciers and snowpack, in regulating the annual runoff cycle over the Andes. Moreover, how climate change will alter these water fluxes and reservoirs, and how the current warming would affect river flows at subtropical and extratropical latitudes, are still open questions. To understand long-term changes (from decades to centuries) in the Andean hydroclimate, we need further research on the longterm water and energy balances over the Andes. For instance, we need to identify if the surface and the atmospheric water balances exhibit a closure in the long-term. Moreover, we need to estimate the strength of the coupling between the surface and the atmospheric water and energy budgets along the different river basins of the Andes. In addition, we need to determine if the hydrological variables over the Andes exhibit long-term trends and/or non-stationaries and their effects on the water balance closure. Here it is relevant to separate the impacts of climate change from those arising from low-frequency natural variability and those related to land use changes.

Local orography strongly modulates the availability of atmospheric moisture and produces local circulations, which are key elements to trigger convection in the tropical and subtropical Andes. In general, air moves upward (downward) during daytime (nighttime) from lower (higher) sectors, adjacent plains and valley floor, to upper (lower) sectors of the tropical and subtropical Andes following slope and valleys, shaping different diurnal cycles of precipitation. In the subtropics and extratropics, frontal precipitation dominates in winter, when orography modifies precipitation systems coming from the Pacific Ocean. In particular, orography affects the precipitating clouds within a passing frontal system and enhances precipitation in the windward (western) side of the Andes by a factor 2-3 with respect to coastal and lowland values at the same latitude. Despite the substantial differences in mountain height and incoming moist-laden westerly flow, still, the mechanisms involved are not clear. Precipitation is, on the other hand, greatly reduced downstream of the Andes, creating a very marked precipitation gradient between southern Chile $(>3,000 \mathrm{~mm} /$ year$)$ and southwestern Argentina $(<300 \mathrm{~mm} /$ year). However, the lack of sufficient number of spatially distributed ground-based measurements of precipitation and other hydroclimatic variables over the Andes (Condom et al., 2020), including the strong limitations of satellite estimates over the Andes (Vallejo-Bernal et al., 2020), severely limits the understanding of the local processes involved in precipitation and surface hydrology in the region. This results in a poor estimation of the precipitation and large residuals (usually negative) in water balances, even for large Andean river basins. An alternative approach to partially tackle both, the role of local processes and the high spatial variability in the Andes is the use of high-resolution (both spatial and temporal) climate model simulations. They could be calibrated in the few regions with dense meteorological networks and with the use of the relatively scarce sub-daily meteorological data available to study the diurnal cycles of diverse hydroclimatic variables. The development of high-resolution simulations in the Andes could provide insights to understand and predict the dynamical and thermodynamic processes, explaining the location of the rain hotspots over regions largely influenced by orographic processes, such as western Colombia, the Amazon-Andes transition zone and western Patagonia. Even more, the role of the vegetation on these rain hotspots zones needs to be deeply explored, and that can be potentially addressed using climate simulations and improving the observational network, as well as improving the observational networks in these regions.

Hydroclimate in the Andes is also modulated by different largescale phenomena such as the tropical easterly waves, aerial and atmospheric rivers, low-level jets, and climatic oscillations, such as MJO, ENSO, SAM, Atlantic SST variability, PDO, and AMO. Although ENSO is the dominant mode of interannual variability of hydroclimate in the Andes, different spatial patterns of SST anomalies over the tropical oceans, like those associated with the ENSO Modoki events in the equatorial Pacific, may induce divergent responses in the Andean hydroclimate. The influence of the tropical North Atlantic has been particularly demonstrated as relevant in the northern Andes and during the winter season in the southern tropical Andes; however, the influences of the South Atlantic Ocean conditions on the hydroclimate on the Andes are largely unknown. Longer timescale phenomena such as the PDO or the AMO also modulate hydroclimate variability in the Andes. In general, further studies focused on this hydroclimate variability in the Andes are relevant for seasonal and subseasonal forecasts in the region.

The current knowledge about the hydroclimatological processes over the Andes highlights the necessity to better understand different phenomena from local to regional scales, and their interactions at different timescales. In addition to the research gaps highlighted in the previous paragraphs of this section, other research necessities emerge. For instance, the Andes are affected by the activity of different low-level jets (see Espinoza et al., 2020; Poveda et al., 2020); therefore, a better understanding is needed on how these lowlevel circulations influence the spatiotemporal variability of rainfall, evapotranspiration, soil moisture and streamflows. The occurrence of mesoscale convective and midlatitude stratiform precipitation systems, and their interactions with these low-level jets and orography in the Andes, needs to be further investigated (e.g., Vera, 2006; Viale et al., 2013; Poveda et al., 2020). In addition, the land-atmosphere interaction among surrounding regions are relevant for the Andes hydroclimate. For example, how changes in the Amazon's vegetation (deforestation or savanization) affect surface and atmosphere water and energy budgets over the Andes across scales is of utmost importance. Moreover, we need to better understand the interconnection of the hydrometeorological, climatological and biogeochemical feedbacks between the Andes, the Amazon and the Pacific Ocean. Finally, since local processes play a key role in the Andes, further research is required on the mechanisms controlling the high amounts of precipitation recycling over the tropical Andes and how much water is sublimated from the dry, snow-capped Andes in the subtropics. 
The above summarized research and knowledge gaps need to be tackled in the ANDEX research agenda. In particular, the improvement of the observational and monitoring networks in the Andes, as well as the development of high-resolution modeling studies, are necessary in order to fill the major research questions related to recurrent local-scales and orographically-induced physical processes in the Andean hydroclimate. In this context, two additional major technical questions emerge: 1) what are the observational requirements (in terms of what to measure and the spatio-temporal scales) to better understand the hydrometeorological processes under climate change in the Andes?, and 2) what is the proper level of complexity and resolution required to tackle the previous research gaps? It is required to address these and other research gaps to improve our understanding of the Andean hydroclimate and its vulnerability to natural variability and human-induced changes.

\section{AUTHOR CONTRIBUTIONS}

All authors listed have made a substantial, direct, and intellectual contribution to the work and approved it for publication.

\section{REFERENCES}

Aceituno, P. (1988). On the functioning of the Southern Oscillation in the South American sector. Part I: surface climate. Mon. Weather Rev. 116, 505-524. doi:10.1175/1520-0493(1988)116<0505:otfots $>2.0 . c 0 ; 2$

Alpert, P. (1986). Mesoscale indexing of the distribution of orographic precipitation over high mountains. J. Clim. Appl. Meteorol. 25, 532-545. doi:10.1175/1520-0450(1986)025<0532:miotdo >2.0.co;2

Alvarez-Villa, O. D., Vélez, J. I., and Poveda, G. (2011). Improved long-term mean annual rainfall fields for colombia. Int. J. Climatol. 31, 2194-2212. doi:10.1002/ joc.2232

Ampuero, A., Strikis, N., Apaéstegui, J., Vuille, M., Novello, V. F., Espinoza, J. C., et al. (2020). The forest effects on the isotopic composition of rainfall in the northwestern Amazon Basin. Journal of Geophysical Research:. Atmosphere 125, e2019JD031445. doi:10.1029/2019JD031445

Aravena, R. (1995). Hidrología isotópica y geoquímica de las aguas subterráneas del norte de chile. Bull. Inst. Fr. Études Andines. 24 (3), 495-504.

Arias, P. A., Martínez, J. A., Mejía, J. D., Pazos, M. J., and Espinoza, J. C. (2020). Changes in normalized difference vegetation index in the orinoco and amazon river basins: links to tropical atlantic surface temperatures. J. Clim. 33 (19), 8537-8559. doi:10.1175/jcli-d-19-0696.1

Arias, P. A., Martínez, J. A., and Vieira, S. C. (2015). Moisture sources to the 20102012 anomalous wet season in northern south america. Clim. Dynam. 45 (9-10), 2861-2884. doi:10.1007/s00382-015-2511-7

Arrieta-Castro, M., Donado-Rodríguez, A., Acuña, G. J., Canales, F. A., Teegavarapu, R. S. V., and Kaźmierczak, B. (2020). Analysis of streamflow variability and trends in the meta river, colombia. Water 12, 1451. doi:10.3390/ w12051451

ANA, (2012). Recursos Hídricos en el Peru, 2nd Edn. Ministerio de Agricultura. Autoridad Nacional del Agua, Lima, 45-189.

Ashok, K., Behera, S. K., Rao, S. A., Weng, H., and Yamagata, T. (2007). El Niño Modoki and its possible teleconnection. J. Geophys. Res. 112, C11007. doi:10. 1029/2006JC003798

Ayala, Á., Farías-Barahona, D., Huss, M., Pellicciotti, F., McPhee, J., and Farinotti, D. (2020). Glacier runoff variations since 1955 in the maipo river basin, in the semiarid andes of central chile. Cryosphere 14, 2005-2027. doi:10. 5194/tc-14-2005-2020

Ayes Rivera, I., Callau Poduje, A. C., Molina-Carpio, J., Ayala, J. M., Armijos, E., Espinoza-Villar, R., et al. (2003-2016). On the relationship between suspended sediment concentration, rainfall variability and groundwater: an empirical and

\section{FUNDING}

This review paper has been achieved as part of the ANDEX program (www.gewex.org/project/andex/), which is a prospective Regional Hydroclimate Project (RHP) of the GEWEX Hydroclimatology Panel (GHP). PA was supported by Universidad de Antioquia through the Grant CODI PRG 2017-16264. JE was supported by the French AMANECERMOPGA project funded by ANR and IRD (ref. ANR-18MPGA-0008). MM was funded by Consejo Nacional de Investigaciones Científicas y Técnicas (CONICET)-Argentina. LS would like to acknowledge the financial support from Triagency Institutional Programs Secretariat of Canada through the Global Water Futures Program, Canada First Research Excellence Fund. MV was supported by FONDECYT 11151009 and FONCYT PICT 2016-1666.

\section{ACKNOWLEDGMENTS}

We acknowledge Pedro Rau for providing Figure 3.

probabilistic analysis for the andean beni river. Bolivia Water 2019 (11), 2497. doi:10. 3390/w11122497

Azócar, G. F., and Brenning, A. (2010). A. Hydrological and geomorphological significance of rock glaciers in the dry andes, chile $\left(27^{\circ}-33^{\circ} \mathrm{S}\right)$. Permafr. Periglac. Process. 21 (1), 42-53. doi:10.1002/ppp.669

Barrett, B. S., Krieger, D. B., and Barlow, C. P. (2011). Multiday circulation and precipitation climatology during winter rain events of differing intensities in central chile. J. Hydrometeorol. 12, 1071-1085. doi:10.1175/2011jhm1377.1

Barrett, B. S., Carrasco, J. F., and Testino, A. P. (2012). Madden-julian oscillation (MJO) modulation of atmospheric circulation and chilean winter precipitation. J. Clim. 25, 1678-1688. doi:10.1175/JCLI-D-11-00216.1

Barrett, B. S., Garreaud, R., and Falvey, M. (2009). Effect of the Andes cordillera on precipitation from a midlatitude cold front. Mon. Weather Rev. 137 (9), 3092-3109.

Bechis, H., Salio, P., and Ruiz, J. J. (2020). Drylines in Argentina: synoptic climatology and processes leading to their genesis. Mon. Weather Rev. 148, MWR-D-19-0050.1. doi:10.1175/MWR-D-19-0050.1

Bedoya-Soto, J. M., Aristizábal, E., Carmona, A. M., and Poveda, G. (2019). Seasonal shift of the diurnal cycle of rainfall over medellin's valley, central andes of colombia (1998-2005). Front. Earth Sci. 7, 92. doi:10.3389/feart. 2019.00092

Bedoya-Soto, J. M., Poveda, G., Trenberth, K., and Vélez, J. J. (2018). Interannual hydroclimatic variability and the 2009-2011 extreme ENSO phases in colombia: from andean glaciers to caribbean lowlands. Theor. Appl. Climatol. 135, 1531-1544. doi:10.1007/s00704-018-2452-2

Bendix, J., Trachte, K., Cermak, J., Rollenbeck, R., and Nauss, T. (2009). Formation of convective clouds at the foothills of the tropical eastern andes (south Ecuador). J. Appl. Meteorol. 48, 1682-1695. doi:10.1175/2009jamc2078.1

Berbery, E. H., and Barros, V. (2000). The hydrologic cycle of the La Plata basin in South America. J. Hydrometeorol. 3, 630-645.

Bookhagen, B., and Strecker, M. R. (2008). Orographic barriers, high-resolution TRMM rainfall, and relief variations along the eastern andes. Geophys. Res. Lett. 35, L06403. doi:10.1029/2007GL032011

Boisier, J. P., Rondanelli, R., Garreaud, R. D., and Muñoz, F. (2016). Anthropogenic and natural contributions to the Southeast Pacific precipitation decline and recent megadrought in central Chile. Geophys. Res. Lett., 43, 413-421. doi:10. 1002/2015GL067265-1266

Bourrel, L., Rau, P., Dewitte, B., Labat, D., Lavado, W., Coutaud, A., et al. (2015). Ordoñez JLow-frequency modulation and trend of the relationship between ENSO and precipitation along the northern to centre peruvian pacific coast. Hydrol. Process. 29 (6), 1252. doi:10.1002/hyp.10247-1266. 
Bozkurt, D., Rondanelli, R., Garreaud, R., and Arriagada, A. (2016). Impact of warmer eastern tropical pacific SST on the march 2015 atacama floods. Mon. Weather Rev. 144 (11), 4441-4460. doi:10.1175/mwr-d-16-0041.1

Builes-Jaramillo, L. A., and Poveda, G. (2018). Conjoint analysis of surface and atmospheric water balances in the andes-amazon system. Water Resour. Res. 54 (5), 3472-3489. doi:10.1029/2017WR021338

Buytaert, W., Celleri, R., Willems, P., De Bièvre, B., and Wyseure, G. (2006). Spatial and temporal rainfall variability in mountain areas: a case study from the south ecuadorian andes. J. Hydrol. 329, 413-421. doi:10.1016/j.jhydrol. 2006.02.031

Buytaert, W., Moulds, S., Acosta, L., de Bievre, B., Olmos, C., Villacis, M., et al. (2017). Glacial melt content of water use in the tropical andes. Environ. Res. Lett. 12, 114014. doi:10.1088/1748-9326/aa926c

Cai, W., McPhaden, M., Grimm, A., Rodrigues, R., Taschetto, A., Garreaud, R., et al. (2020). Climate impacts of el niño-southern oscillation on south america. Nat. Rev. Earth Environ. 1, 215-231. doi:10.1038/s43017-020-0040-3

Campozano, L., Celleri, R., Trachte, K., Bendix, J., and Samaniego, E. (2016). Rainfall and cloud dynamics in the andes: a southern ecuador case study. $A d v$. Meteorol. 2016, 3192765. doi:10.1155/2016/3192765

Campozano, L., Robaina, L., and Samaniego, E. (2020). The Pacific decadal oscillation modulates the relation of ENSO with the rainfall variability in coast of ecuador. Int. J. Climatol. 40 (13), 5801-5812. doi:10.1002/joc.6525

Campozano, L., Trachte, K., Célleri, R., Samaniego, E., Bendix, J., Albuja, C., et al. (2018). Climatology and teleconnections of mesoscale convective systems in an andean basin in southern Ecuador: the case of the paute basin. Adv. Meteorol. 2018, 1-13. doi:10.1155/2018/4259191

Chaffaut, I. (1998). "Precipitations d'altitude, eaux souterraines et changements climatiques de l'altiplano nord-chilien. these presenté pour obtenir le grade de docteur en sciences," in Université paris XI orsay, octubre 1998. Editors J. Araya, P. Pierre, A. Marc, A. Covarrubias, R. Espejo, L. Nelda, L. Vargas. (Paris).

Chavez, S. P., and Takahashi, K. (2017). Orographic rainfall hotspots in the andesamazon transition according to the TRMM precipitation radar and in situ data. J. Geophys. Res. Atmos. 122 (11), 5870-5882. doi:10.1002/2016JD026282

Chow, F. K., De Wekker, S. F. J., and Snyder, B. J. (2013). "Recent progress and current challenges," in Mountain weather research and forecasting. The Netherlands: Springer, 750.

Condom, T., Martínez, R., Pabón, J. D., Costa, F., Pineda, L., Nieto, J. J., et al. (2020). Climatological and hydrological observations for the south american andes: in-situ stations, satellite and reanalysis data sets. Front. Earth Sci. 8, 92. doi:10.3389/feart.2020.00092

Coudrain, A., Loubet, M., Condom, T., Talbi, A., Ribstein, P., Pouyaud, B., et al. (2002). Donnees isotopiques ( $87 \mathrm{Sr} / 86 \mathrm{Sr}$ ) et changements hydrologiques depuis 15000 ans sur l'altiplano andin. Hydrol. Sci. J. 47, 293-306. doi:10.1080/ 02626660209492931

Dollfus, O. (1964). Cambios climáticos cuaternarios en los andes peruanos. boletin de la sociedad geografica. Lima. 83, 65-74.

Dussaillant, I., Berthier, E., Brun, F., Masiokas, M., Hugonnet, R., and Favier, V. (2019). Two decades of glacier mass loss along the andes. nat. Geoscience 12, 802-808. doi:10.1038/s41561-019-0432-5

Espinoza, J. C., Chavez, S., Ronchail, J., Junquas, C., Takahashi, K., and Lavado, W. (2015). Rainfall hotspots over the south tropical andes: spatial distribution, rainfall intensity and relations with largescale atmospheric circulation. Water Resour. Res. 51, 3459-3475. doi:10.1002/2014wr016273

Espinoza, J. C., Garreaud, R., Poveda, G., Arias, P. A., Molina-Carpio, J., Masiokas, M., et al. (2020). Hydroclimate of the andes. Part I: main climatic features. Front. Earth Sci. 8, 64. doi:10.3389/feart.2020.00064

Espinoza, J. C., Ronchail, J., Guyot, J. L., Cochonneau, G., Naziano, F., Lavado, W., et al. (2009a). Spatio-temporal rainfall variability in the amazon basin countries (Brazil, Peru, Bolivia, Colombia, and Ecuador). Int. J. Climatol. 29, 1574-1594. doi:10.1002/joc.1791

Espinoza, J. C., Guyot, J. L., Ronchail, J., Cochonneau, G., Filizola, N., Fraizy, P., et al. (2009b). Contrasting regional discharge evolutions in the amazon basin (1974-2004). J. Hydrol. 375, 297-311. doi:10.1016/j.jhydrol.2009. 03.004

Espinoza, J. C., Ronchail, J., Guyot, J. L., Junquas, C., Vauchel, P., Lavado, W., et al. (2011). Climate variability and extreme drought in the upper solimões River (western Amazon Basin): understanding the exceptional 2010 drought. Geophyisical Res. Lett. 38, 1-6. doi:10.1029/2011GL047862
Espinoza, J. C., Marengo, J. A., Ronchail, J., Molina, J., Noriega, L., and Guyot, J. L. (2014). The extreme 2014 flood in south-western amazon basin: the role of tropical-subtropical south atlantic SST gradient. Environ. Res. Lett. 9, 124007. doi:10.1088/1748-9326/9/12/124007

Espinoza, J. C., Ronchail, J., Marengo, J. A., and Segura, H. (2019). Contrasting North-South changes in Amazon wet-day and dry-day frequency and related atmospheric features (1981-2017). Clim. Dynam. 52 (9-10), 5413-5430. doi:10. 1007/s00382-018-4462-2

Falvey, M., and Garreaud, R. D. (2005). Moisture variability over the South American Altiplano during the South American low level jetexperiment (SALLJEX) observing season. J. Geophy. Res. 110, D22105. doi:10.1029/ 2005JD006152

Falvey, M., and Garreaud, R. (2007). Wintertime precipitation episodes in central Chile: associated meteorological conditions and orographic influences. J. Hydrometeorol. 8 (2), 171-193. doi:10.1175/jhm562.1

FAO (1998). Crop evapotranspiration-guidelines for computing crop water requirements-FAO Irrigation and drainage. Available at: http://www.fao.org/ 3/x0490e/x0490e00.htm\#Contents (Accessed May 20, 2020).

Flores-Rojas, J. L., Cuxart, J., Piñas-Laura, M., Callañaupa, S., Suárez-Salas, L., Kumar, S., et al. (2019a). Seasonal and diurnal cycles of surface boundary layer and energy balance in the central andes of perú, mantaro valley. Atmosphere 10, 779. doi:10.3390/atmos10120779

Florez-Rojas, J. L., Alvarez, A. S. M., Kumar, S., Castro, D. M., Puma, E. V., and Silva, F. Y. (2019b). Analysis of possible triggering mechanisms of severe thunderstorms in the tropical central andes of peru, mantaro valley. Atmosphere 10, 301. doi:10.3390/atmos10060301

Garreaud, R., Alvarez-Garreton, C., Barichivich, J., Boisier, J. P., Christie, D., Galleguillos, M., et al. (2017). The 2010-2015 mega drought in central chile: impacts on regional hydroclimate and vegetation. Hydrol. Earth Syst. Sci. 21, 6307-6327. doi:10.5194/hess-2017-191

Garreaud, R. D. (1999). Multiscale Analysis of the summertime precipitation over the central andes. Mon. Weather Rev. 127, 901-921. doi:10.1175/15200493(1999) $127<0901$ :maotsp >2.0.co;2

Garreaud, R. D. (2009). The Andes climate and weather. Adv. Geosci. 22, 3-11. doi:10.5194/adgeo-22-3-2009

Garreaud, R. D. (2018). A plausible atmospheric trigger for the 2017 coastal el niño. Int. J. Climatol. 38, 1296-1302. doi:10.1002/joc.5426

Garreaud, R. D., Vuille, M., Compagnucci, R., and Marengo, J. (2009). Present-day south american climate. Palaeogeogr. Palaeoclimatol. Palaeoecol. 281, 180-195. doi:10.1016/j.palaeo.2007.10.032

Garreaud, R., Vuille, M., and Clement, A. (2003). The climate of the Altiplano: observed current conditions and mechanisms of past changes. Palaeogeogr. Palaeoclimatic. Palaeoecol. 194, 5-22.

Garreaud, R., Lopez, P., Minvielle, M., and Rojas, M. (2013). Large scale control on the Patagonia climate. J. Clim. 26, 215-230.

Garreaud, R., Falvey, M., and Montecinos, A. (2016). Orographic precipitation in coastal southern Chile: mean distribution, temporal variability, and linear contribution. J. Hydrometeorol. 17 (4), 1185-1202.

Garreaud, R. D., Boisier, J. P., Rondanelli, R., Montecinos, A., Sepúlveda, H. H., and Veloso-Aguila, D. (2020). The central chile mega drought (2010 -2018): a climate dynamics perspective. Int. J. Climatol. 40, 421-439. doi:10.1002/joc. 6219

Gascoin, S., Lhermitte, S., Kinnard, C., Bortels, K., and Liston, G. E. (2013). Wind effects on snow cover in Pascua-Lama, dry andes of chile. Adv. Water Resour. 55, 25-39. doi:10.1016/j.advwatres.2012.11.013

Geerts, B. (2017). The 2015 Plains Elevated Convection at Night Field Project. Bull. Amer. Meteor. Soc. 98, 767-786. doi:10.1175/BAMS-D-15-00257.1

Gillett, N. P., Kell, T. D., and Jones, P. D. (2006). Regional climate impacts of the southern annular mode. Geophys. Res. Lett. 33 (23). doi:10.1029/2006GL027721

Giovannettone, J. P., and Barros, A. P. (2009). Probing regional orographic controls of precipitation and cloudiness in the central Andes using satellite data. J. Hydrometeorol. 10, 167-182.

González-Reyes, A., McPhee, J., Christie, D. A., Le Quesne, C., Szejner, P., Masiokas, M. H., et al. (2017). Spatiotemporal variations in hydroclimate across the mediterranean andes $\left(30^{\circ}-37^{\circ} \mathrm{S}\right)$ since the early twentieth century. J. Hydrometeorol. 18, 1929-1942. doi:10.1175/JHM-D-16-0004.1

Grimm, A. M. (2019). Madden-julian oscillation impacts on south american summer monsoon season: precipitation anomalies, extreme events, 
teleconnections, and role in the MJO cycle. Clim. Dynam. 53, 907-932. doi:10. 1007/s00382-019-04622-6

Grimm, A. M., and Ambrizzi, T. (2009). Teleconnections into South America from the tropics and extratropics on interannual and intraseasonal timescales. In: Vimeux, F., Sylvestre, F. and Khodri, M., editors. Past climate variability in South America and surrounding regions: from the last glacial maximum to the Holocene, Springer, Apeldoorn, 159-191. Available at: http://dx.doi.org/10. 1007/978-90-481-2672-9_7

Guyot, J. L. (1993). Hydrogéochimie des fleuves de l'amazonie bolivienne, editions de l'ORSTOM. (Paris: INSTITUT FRANCAIS DE RECHERCHE SCIENTIFIQUE POUR LE DÉVELOPPEMENT EN COOPÉRATION) 261.

Hierro, R., Pessano, H., Llamedo, P., de la Torre, A., Alexander, P., and Odiard, A. (2013). Orographic effects related to deep convection events over the Andes region. Atmos. Atmos. Res. 120-121. doi:10.1016/j.atmosres.2012.08.020

Houston, J., and Hartley, A. J. (2003). The central Andean west-slope rainshadow and its potential contribution to the origin of hyper-aridity in the atacama desert. Int. J. Climatol. 322 (23), 1453-1464. doi:10.1002/joc.938

Hoyos, I., Dominguez, F., Cañón-Barriga, J., Martínez, J. A., Nieto, R., Gimeno, L., et al. (2017). Moisture origin and transport processes in colombia, northern south america. Clim. Dynam. 1-20. doi:10.1007/s00382-017-3653-6

Huerta, A., and Lavado-Casimiro, W. (2020). Trends and variability of precipitation extremes in the peruvian altiplano (1971-2013). Int. J. Clim. [Epub ahead of print]. doi:10.1002/joc.6635

Hunziker, S., Brönnimann, S., Calle, J., Moreno, I., Andrade, M., Ticona, L., et al. (2018). Effects of undetected data quality issues on climatological analyses. Clim. Past. 14, 1-20. doi:10.5194/cp-14-1-2018

Imfeld, N., Schuller, C. B., Marrou, K. M. C., Jaques-Cooper, M., Sedlmeier, K., Gubler, S., et al. (2019). Summertime precipitation deficits in the southern peruvian highlands since 1964. Int. J. Climatol. 39 (11), 4497-4513. doi:10.1002/ joc. 6087

Imfeld, N., Sedlmeier, K., Gubler, S., Marrou, K. C., Davila, C. P., Huerta, A., et al. (2020). A combined view on precipitation and temperature climatology and trends in the southern andes of peru. Int. J. Climatol. 1-20. doi:10.1002/joc.6645

Jacques-Coper, M., and Garreaud, R. D. (2015). Characterization of the 1970s climate shift in South America. Int. J. Climatol. 35, 2164-2179. doi:10.1002/joc. 4120

Johnson, A. M. (1976). "The climate of peru, bolivia, and ecuador. climates of central and south america," in World survey of climatology. (New York: Elsevier Scientific Publishing Company), Chap. 4, Vol. 12, 147-218.

Jones, C., and Carvalho, L. M. V. (2002). Active and break phases in the south american monsoon system. J. Clim. 15, 905-914. doi:10.1175/1520-0442(2002) 015<0905:aabpit>2.0.co;2

Jones, C., and Carvalho, L. M. V. (2018). The influence of the atlantic multidecadal oscillation on the eastern andes low-level jet and precipitation in south america. NPJ Clim. Atmos. Sci. 1, 1-7. doi:10.1038/s41612-018-0050-8

Juliá, C., Rahn, D. A., and Rutllant, J. A. (2012). Assessing the influence of the MJO on strong precipitation events in subtropical, semi-arid north-central chile (30º). J. Clim. 25, 7003-7013. doi:10.1175/JCLI-D-11-00679.1

Junquas, C., Takahashi, K., Condom, T., Espinoza, J. C., Chavez, S., Sicart, J. E., et al. (2018). Understanding the influence of orography over the precipitation diurnal cycle and the associated atmospheric processes in the central andes. Clim. Dynam. 50 (11-12), 3995-4017. doi:10.1007/ s00382-017-3858-8

Kayano, M. T., Andreoli, R. V., and Souzade, R. A. F. (2019). El niño-southern oscillation related teleconnections over south America under distinct atlantic multidecadal oscillation and pacific interdecadal oscillation backgrounds: la niña. Int. J. Climatol. 39, 1359-1372. doi:10.1002/joc.5886

Kayano, M. T., and Capistrano, V. B. (2014). How the atlantic multidecadal oscillation (AMO) modifies the ENSO influence on the south american rainfall. Int. J. Climatol. 34, 162-178. doi:10.1002/joc.3674

Kreft, S., Eckstein, D., and Melchior, I. (2016). Global climate risk index 2017: who suffers most from extreme weather events, Weather-related loss events in 2015 and 1996 to 2015. Berlin: Germanwatch e.V.

Krogh, S. A., Pomeroy, J. W., and McPhee, J. (2015). Physically based mountain hydrological modeling using reanalysis data in patagonia. J. Hydrometeorol. 16 (2007), 172-193. doi:10.1175/JHM-D-13-0178.1

Kumar, S., Vidal, S.-Y., Moya-Álvarez, A. S., and Martínez-Castro, D. (2019). Effect of the surface wind flow and topography on precipitating cloud systems over the andes and associated amazon basin: GPM observations. Atmos. Res. 225, 193-208. doi:10.1016/j.atmosres.2019.03.027

Kumar, S., Moya-Álvarez, A. S., Castillo-Velarde, C. D., Martinez-Castro, D., and Silva, Y. (2020a). Effect of low-level flow and Andes mountain on the tropical and mid-latitude precipitating cloud systems: GPM observations. Theor. Appl. Climatol. 141, 157-172. doi:10.1007/s00704-020-03155-x

Kumar, S., Castillo-Velarde, C. D., Prado, V. J. M., Rojas, F. J. L., Gutierrez, C. S. M., Moya Alvarez, A. S., et al. (2020b). Rainfall characteristics in the mantaro basin over tropical andes from a vertically pointed profile rain radar and in-situ field campaign. Atmosphere 11, 248. doi:10.3390/atmos11030248

Lagos, P., Silva, Y., Nickl, E., and Mosquera, K. (2008). El Niño -related precipitation variability in peru. Adv. Geosci. 14, 231-237. doi:10.5194/ adgeo-14-231-2008

Lara, A., Villalba, R., and Urrutia, R. (2008). A 400-year tree-ring record of the Pueblo River summer-fall streamflow in the valdivian rainforest eco-region, chile. Clim. Change 86, 331-356. doi:10.1007/s10584-007-9287-7

Laraque, A., Ronchail, J., Cochonneau, G., Pombosa, R., and Guyot, J. L. (2007). Heterogeneous distribution of rainfall and discharge regimes in the ecuadorian amazon basin. J. Hydrometeorol. 8, 1364-1381. doi:10.1175/2007jhm784.1

Larkin, N. K., and Harrison, D. E. (2005). On the definition of El Niño and associated seasonal average U.S. weather anomalies. Geophys. Res. Lett. 32, L13705. doi:10.1029/2005GL022738

Lavado, W., and Espinoza, J. C. (2014). Impactos de El Niño y La Niña en las lluvias del perú (1965-2007). Revista Brasileira de Meteorologia 29, 171-182. doi:10. 1590/S0102-77862014000200003

Lavado-Casimiro, W., Labat, D., Guyot, J. L., and Ardoin-Bardin, S. (2011). Assessment of climate change impacts on the hydrology of the peruvian amazon-andes basin. Hydrol. Process. 25 (24), 3721-3734. doi:10.1002/hyp. 8097

Lavado-Casimiro, W., Labat, D., Ronchail, J., Espinoza, J. C., and Guyot, J. L. (2013). Trends in rainfall and temperature in the Peruvian Amazon-Andes basin over the last 40 years (1965-2007). Hydrol. Process. 41, 2944-2957. doi:10. 1002/hyp.9418

Lavado-Casimiro, W. S., Ronchail, J., Labat, D., Espinoza, J. C., and Guyot, J. L. (2012). Basin-scale analysis of rainfall and runoff in Peru (1969-2004): Pacific, Titicaca and Amazonas drainages. Hydrol. Sci. J. 57. doi:10.1080/02626667. 2012.672985

Li, Y., and Smith, R. B. (2010). The detection and significance of diurnal pressure and potential vorticity anomalies east of the rockies. J. Atmos. Sci. 67, 2734-2751. doi:10.1175/2010JAS3423.1

Loaiza Cerón, W., Andreoli, R. V., Kayano, M. T., Ferreira de Souza, R. A., Jones, C., and Carvalho, L. M. V. (2020). The influence of the atlantic multidecadal oscillation on the choco low-level jet and precipitation in colombia. Atmosphere 11, 174. doi:10.3390/atmos11020174

López, M. E., and Howell, W. E. (1967). Katabatic winds in the Equatorial Andes, J. Atmos. Sci. 24 (1), 29-35.

MacDonell, S., Kinnard, C., Mölg, T., Nicholson, L., and Abermann, J. (2013). Meteorological drivers of ablation processes on a cold glacier in the semi-arid andes of chile. Cryosphere 7, 1513-1526. doi:10.5194/tc-7-1513-2013

Madden, R. A., and Julian, P. R. (1994). Observations of the 40-50-day tropical oscillation-a review. Mon. Weather Rev. 122, 814-837. doi:10.1175/15200493(1994) $122<0814$ :ootdto $>2.0 . c 0 ; 2$

Marengo, J. A. (2009). Long-term trends and cycles in the hydrometeorology of the amazon basin since the late 1920s. Hydrol. Process. 23, 3236-3244. doi:10.1002/ hyp.7396

Marengo, J. A., and Espinoza, J. C. (2016). Extreme seasonal droughts and floods in amazonia: causes, trends and impacts. Int. J. Climatol. 36 (3), 1033-1050. doi:10.1002/joc. 4420

Martinez, J. A., and Dominguez, F. (2014). Sources of atmospheric moisture for the la plata river basin. J. Clim. 27, 6737-6753. doi:10.1175/JCLI-D-14-00022.1

Masiokas, M. H., Cara, L., Villalba, R., Pitte, P., Luckman, B. H., Toum, E., et al. (2019). Streamflow variations across the andes $\left(18^{\circ}-55^{\circ} \mathrm{S}\right)$ during the instrumental era. Sci. Rep. 9, 17879. doi:10.1038/s41598-019-53981-x

Masiokas, M. H., Villalba, R., Luckman, B. H., Le Quesne, C., and Aravena, J. C. (2006). Snowpack variations in the central andes of argentina and chile, 1951-2005: large-scale atmospheric influences and impli-cations for water resources in the region. J. Clim. 19, 6334-6352. doi:10.1175/ jcli3969.1 
Massmann, A., Minder, J., Garreaud, R., Kingsmill, D., Valenzuela, R., Montecinos, A., Fults, S., and Snider, J. (2017). The chilean coastal orographic precipitation experiment: observing the influence of microphysical rain regime on coastal orographic precipitation. J. Hydrometeorol. 18 (10), 2723-2743. doi:10.1175/ jhm-d-17-0005.1

Mauget, M. H., Rabatel, A., Rivera, A., Ruiz, L., Pitte, P., Ceballos, J. L., et al. (2020). Current state and recent changes of the cryosphere in the andes. Front. Earth Sci. 8, 99. doi:10.3389/feart.2020.00099

Mayta, V. C., Ambrizzi, T., Espinoza, J. C., and Silva Dias, P. L. (2019). The role of the madden-julian oscillation on the amazon basin intraseasonal rainfall variability. Int. J. Climatol. [Epub ahead of print]. doi:10.1002/joc.5810

Mejía, J. F., Mesa, O. J., Poveda, G., Vélez, J., Hoyos, C., Mantilla, R., et al. (1999). Distribución espacial y ciclos anual y semianual de la precipitación en colombia. Dyna. 127, 7-26.

Minvielle, M., and Garreaud, R. D. (2011). Projecting rainfall changes over the south american altiplano. J. Clim. 24 (17), 4577-4583. doi:10.1175/jcli-d-1100051.1

Mo, K. C., and Higgins, R. W. (1998). The Pacific -South American modes and tropical convection during the Southern Hemisphere Winter. Mon. Weather Rev. 126 (6), 1581-1596.

Mohr, K. I., Slayback, D., and Yager, K. (2014). Characteristics of precipitation features and annual rainfall during the TRMM era in the central andes. J. Clim. 27 (11), 3982-4001. doi:10.1175/jcli-d-13-00592.1

Molina, R., Salazar, J. F., Martínez, J. A., Villegas, J. C., and Arias, P. A. (2019). Exponential growth of precipitation along a "forest-fed moisture conveyor belt" above the amazon. J. Geophys. Res. Atmos. 124, 2589-2599. doi:10.1029/ 2018JD029534

Molina-Carpio, J. (2007). Agua y Recurso Hídrico en el Sudoeste de Potosí. Cochabamba: Publicación FOBOMADE, 72.

Molina-Carpio, J., Espinoza, J. C., Coritza, E., Salcedo, F., Farfán, C., Mamani, L., et al. (2019). Climate and spatial variability of the humid upper andes. Ecología en Bolivia. 54 (1), 40-56.

Molina-Carpio, J., Espinoza, J. C., Vauchel, P., Ronchail, J., Gutierrez, B., Guyot, J. L., et al. (2017). The hydroclimatology of the upper madeira river basin: spatio-temporal variability and trends (1967-2013). Hydrol. Sci. J. 62 (6), 911-927. doi:10.1080/02626667.2016.1267861

Molina-Carpio, J., Salcedo, F., and Vauchel, P. (2007). Balance hídrico de cuencas montañosas húmedas. $2 a$ reunión científica ORE-HYBAM. Manaus.

Molina-Carpio, J., Satgé, F., and Pillco, R. (2014). "Los recursos hídricos del sistema TDPS," in Línea base de conocimientos sobre los recursos hidrológicos e hidrobiológicos en el sistema TDPS con enfoque en la cuenca del Lago Titicaca. Editors M. Pouilly, X. Lazzaro, and D. Point (Quito: IUCN-IRD), 19-43.

Montecinos, A., and Aceituno, P. (2003). Seasonality of the ENSO-related rainfall variability in central Chile and associated circulation anomalies. J. Clim. 16, 281-296. doi:10.1175/1520-0442(2003)016<0281:soterr >2.0.co;2

Montecinos, A., Díaz, A., and Aceituno, P. (2000). Seasonal diagnostic and predictability of rainfall in subtropical south america based on tropical pacific SST. J. Clim. 13, 746-758. doi:10.1175/1520-0442(2000)013<0746: sdapor $>2.0 . \mathrm{co} ; 2$

Moquet, J.-S. (2011). Chemical weathering and atmospheric/soil CO2 uptake in the andean and foreland amazon basins. Chem. Geol. 287 (1-2), 1-26. doi:10.1016/ j.chemgeo.2011.01.005

Mora, D. E., and Willem, P. (2012). Decadal oscillations in rainfall and air temperature in the Paute River Basin -Southern Andes of Ecuador. Theor Appl. Climatol. 108, 267-282. doi:10.1007/s00704-011-0527-4

Morales, J. S., Arias, P. A., Martínez, J. A., and Durán-Quesada, A. M. (2020). The role of low-level circulation on water vapor transport to central and northern south america: insights from a 2D Lagrangian approach. Int. J. Climatol. [Epub ahead of print]. doi:10.1002/joc.6873

Mundo, I., Masiokas, M., Villalba, R., Morales, M., Neukom, R., Quesne, C., et al. (2012). Multi-century tree-ring based reconstruction of the neuquén river streamflow, northern patagonia, argentina. Clim. Past. 8, 815-829. doi:10. 5194/cp-8-815-2012

Muñoz, A. A., González-Reyes, A., and Lara, A. (2016). Streamflow variability in the Chilean temperate-mediterranean climate transition $\left(35^{\circ} \mathrm{S}-42^{\circ} \mathrm{S}\right)$ during the last 400 years inferred from tree-ring records. Clim. Dyn. 47, 4051-4066. doi:10. 1007/s00382-016-3068-9
Navarro-Monterroza, E., Arias, P. A., and Vieira, S. C. (2019). El Niño-oscilación del sur, fase modoki, y sus efectos en la variabilidad espacio-temporal de la precipitación en colombia. revista de la acadamia colombiana de ciencias exactas. Físicas y Naturales. 43 (166), 120-132. doi:10.18257/raccefyn.704

Neukom, R., Rohrer, M., Calanca, P., Salzmann, N., Huggel, C., Acuña, D., et al. (2015). Facing unprecedented drying of the central Andes? Precipitation variability over the period AD 1000-2100. Environ. Res. Lett. 10, 084017. doi:10.1088/1748-9326/10/8/084017

Olarinoye, T., Gleeson, T., and Marx, V. (2020). Global karst springs hydrograph dataset for research and management of the world's fastest-flowing groundwater. Sci. Data. 7 (59), 4090. doi:10.1038/s41597-019-0346-5

Oster, R. (1979). Las precipitaciones en colombia. revista colombia geográfica, instituto agustín codazzi. Bogotá. VI, 5-147.

Pabón-Caicedo, J. D., Arias, P. A., Carril, A. F., Espinoza, J. C., Goubanova, K., Lavado, W., et al. (2020). Observed and projected hydroclimate changes in the andes. Front. Earth Sci. 8, 61. doi:10.3389/feart.2020.00061

Paccini, L., Espinoza, J. C., Ronchail, J., and Segura, H. (2017). Intraseasonal rainfall variability in the Amazon basin related to large-scale circulation patterns: a focus on western amazon-andes transition region. Int. J. Climatol. [Epub ahead of print]. doi:10.1002/joc.5341

Pasquini, A., and Depetris, P. (2007). Discharge trends and flow dynamics of South American rivers draining the southern atlantic seaboard: an overview. J. Hydrol. 333, 385-399. doi:10.1016/j.jhydrol.2006.09.005

Pasquini, A., and Depetris, P. (2011). Southern patagonia's perito moreno glacier, lake argentino, and santa cruz river hydrological system: an overview. J. Hydrol. 405, 48-56. doi:10.1016/j.jhydrol.2011.05.009

Pittock, A. B. (1980). Pattern of climate variability in argentina and chile-I: precipitation, 1931-60. Mon. Weather Rev. 108, 1347-1361.

Poveda, G. (2004). La hidroclimatología de colombia: una síntesis desde la escala interdecadal hasta la escala diurna. Revista academia colombiana de ciencias exactas. Físicas y Naturales. 28 (107), 201-222.

Poveda, G., Álvarez, D. M., and Rueda, O. A. (2011). Hydro-climatic variability over the andes of colombia associated with ENSO: a review of climatic processes and their impact on one of the Earth's most important biodiversity hotspots. Clim. Dynam. 36 (11-12), 2233-2249. doi:10.1007/s00382-010-0931-y

Poveda, G., Espinoza, J. C., Zuluaga, M. D., Solman, S. A., Garreaud, R., and van Oevelen, P. J. (2020). High impact weather events in the andes. Front. Earth Sci. 8, 162. doi:10.3389/feart.2020.00162

Poveda, G., Jaramillo, L., and Vallejo, L. F. (2014). Seasonal precipitation patterns along pathways of South American low-level jets and aerial rivers. Water Resour. Res. 50, 98-118. doi:10.1002/2013WR014087

Poveda, G., and Mesa, O. J. (2000). On the existence of Lloró (the rainiest locality on Earth): enhanced ocean-atmosphere-land interaction by a low-level jet. Geophys. Res. Lett. 27, 1675-1678. doi:10.1029/1999gl006091

Poveda, G., Mesa, O. J., Salazar, L. F., Arias, P. A., Moreno, H. A., Vieira, S. C., et al. (2005). Diurnal cycle of precipitation in the tropical andes of colombia. Mon. Weather Rev. 133 (No.1), 228-240. doi:10.1175/mwr-2853.1

Poveda, G., Moncada, O., Waylen, P. R., and Rasmussen, R. (2019). “The pluviometric optimum on the Andes of Colombia," in Poster2019 American geophysical union fall meeting, A24K-09. (San Francisco, CA: American Geophysical Union), 9-13.

Poveda, G., Waylen, P. R., and Pulwarty, R. (2006). Modern climate variability in northern south america and southern mesoamerica. Palaeogeogr. Palaeoclimatol. Palaeoecol. 234, 3-27. doi:10.1016/j.palaeo.2005.10.031

Pulwarty, R. S., Barry, R. G., Hurst, C. M., Sellinger, K., and Mogollon, L. F. (1998). Precipitation in the venezuelan andes in the context of regional climate. Meteorol. Atmos. Phys. 67, 217-237.

Quinn, W. H., and Neal, V. T. (1983). Long-term variations in the southern oscillation, el Niño and Chilean subtropical rainfall. Fish. Bull. 81, 363-374.

Rabatel, A., Francou, B., Soruco, A., Gomez, J., Cáceres, B., Ceballos, J. L., et al. (2013). Current state of glaciers in the tropical Andes: a multi-century perspective on glacier evolution and climate change. Cryosphere [Epub ahead of print]. doi:10.5194/tc-7-81-2013

Rasmussen, K. L., and Houze Jr, R. A. (2011). Orogenic convection in subtropical South America as seen by the TRMM satellite. Mon. Weather Rev., 139, 2399-2420. doi:10.1002/joc.4693

Rau, P., Bourrel, L., Labat, D., Melo, P., Dewitte, B., Frappart, F., et al. (2016). Regionalization of rainfall over the peruvian pacific slope and coast. Int. J. Climatol. 37 (1), 143-158. doi:10.1002/joc.4693 
Rau, P., Bourrel, L., Labat, D., Frappart, F., Ruelland, D., Lavado, W., et al. (2017). Hydroclimatic change disparity of Peruvian Pacific drainage catchments. Theor. Appl. Climatol. 1-15. doi:10.1007/s00704-017-2263-x

Recalde-Coronel, G. C., Barnston, A. G., and Muñoz, A. G. (2014). Predictability of december-april rainfall in coastal and andean ecuador. J. Appl. Meteor. Climatol. 53, 1471-1493. doi:10.1175/JAMC-D-13-0133.1

Recalde-Coronel, G. C., Zaitchik, B., and Pan, W. K. (2020). Madden-Julian oscillation influence on sub-seasonal rainfall variability on the west of south america. Clim. Dyn. 54, 2167-2185. doi:10.1007/s00382-019-05107-2

Renwick, J. A., and Revell, M. J. (1999). Blocking over the south pacific and rossby wave propagation. Mon. Weather Rev. 127, 2233-2247.

Réveillet, M., Macdonell, S., Gascoin, S., Kinnard, C., Lhermitte, S., and Schaffer, N. (2019). Uncertainties in the spatial distribution of snow sublimation in the semi-arid andes of chile. Cryosphere Discuss. 1-34, 1-34. doi:10.5194/tc2019-31

Rivera, J. A., Penalba, O. C., Villalba, R., and Araneo, D. C. (2017). Spatio-temporal patterns of the 2010-2015 extreme hydrological drought across the central andes, argentina. Water 9, 652. doi:10.3390/w9090652

Roche, M. A., Aliaga, A., Campos, J., Pena, J., Cortes, J., and Rocha, N. (1990). Hétéréogéneité des précipitations sur la cordillère des andes boliviennes. hydrology in mountainous regions. I-hydrological measurements; the water cycle. IAHS 193, 381-388.

Rollenbeck, R., and Bendix, J. (2011). Rainfall distribution in the Andes of southern Ecuador derived from blending weather radar data and meteorological field observations. Atmos. Res. 99 (2), 277-289. doi:10. 1016/j.atmosres.2010.10.018

Romatschke, U., and Houze, R. A., Jr (2013). Characteristics of precipitating convective systems accounting for the summer rainfall of tropical and subtropical south america. J. Hydrometeorol. 14 (1), 25-46. doi:10.1175/ JHM-D-12-060.1

Ronchail, J., and Gallaire, R. (2006). ENSO and rainfall along the zongo valley (Bolivia) from the Altiplano to the amazon basin. Int. J. Climatol. 26, 1223-1236. doi:10.1002/joc.1296

Rondanelli, R., Hatchett, B., Rutllant, J., Bozkurt, D., and Garreaud, R. (2019). Strongest MJO on record triggers extreme atacama rainfall and warmth in antarctica. Geophys. Res. Lett. 46, 3482-3491. doi:10.1029/2018gl081475

Rondanelli, R., Molina, A., and Falvey, M. (2015). The atacama surface solar maximum. Bull. Am. Meteorol. Soc. 96, 405-418. doi:10.1175/BAMS-D-13-00175.1

Rotunno, R., Klemp, J. B., and Weisman, M. L. (1988). A theory for strong, longlived squall lines. J. Atmos. Sci. 45 (3), 463-485.

Rubin, M. J. (1955). An investigation of relationships between northern and southern hemispheres meteorological parameters. Notes 4, 122-126.

Ruiz-Vasquez, M., Arias, P. A., Martinez, J. A., and Espinoza, J. C. (2020). Effects of amazon basin deforestation on regional atmospheric circulation and water vapor transport towards tropical south america. Clim. Dynam. 54 (9), 4169-4189. doi:10.1007/s00382-020-05223-4

Rutllant, J., and Fuenzalida, H. (1991). Synoptic aspects of the central Chile rainfall variability associated with the southern oscillation. Int. J. Climatol. 11, 63-76.

Saavedra, M., Junquas, C., Espinoza, J. C., and Silva, Y. (2020). Impacts of topography and land use change on the air surface temperature and precipitation over the central peruvian andes. Atmos. Res. 234, 104711. doi:10.1016/j.atmosres.2019.104711

Saavedra, M., and Takahashi, K. (2017). Physical controls on frost events in the central andes of peru using in situ observations and energy flux models. Agric. For. Meteorol. 239, 58-70. doi:10.1016/j.agrformet.2017.02.019

Sakamoto, M., Ambrizzi, T., and Poveda, G. (2011). Moisture sources and life cycle of convective systems over western colombia. Adv. Meteorol. 11, 890759. doi:10. $1155 / 2011 / 890759$

Satgé, F., Espinoza, R., Pillco, Z. R., Roig, H., Timouk, F., Molina, J., et al. (2017). Role of climate variability and human activity on poopó lake droughts between 1990 and 2015 assessed using remote sensing data. Rem. Sens. 9, 1-17. doi:10. $3390 /$ rs 9030218

Scaff, L., Rutllant, J. A., Rahn, D., Gascoin, S., and Rondanelli, R. (2017). Meteorological interpretation of orographic precipitation gradients along an andes west slope basin at $30^{\circ} \mathrm{S}$ (elqui valley, Chile). J. Hydrometeorol. 18 (3), 713-727.doi:10.1175/JHM-D-16-0073.1
Schoolmeester, T., Johansen, K. S., Alfthan, B., Baker, E., Hesping, M., and Verbist, K. (2018). The Andean glacier and water atlas-the impact of glacier retreat on water resources. UNESCO and GRID-arendal, 80.

Segura, H., Espinoza, J. C., Junquas, C., Lebel, T., Vuille, M., and Garreaud, R. (2020). Recent changes in the precipitation-driving processes over the southern tropical andes/western amazon. Clim. Dynam. 54 (5-6), 2613-2631. doi:10. 1007/s00382-020-05132-6

Segura, H., Espinoza, J. C., Junquas, C., and Takahashi, K. (2016). Evidencing decadal and interdecadal hydroclimatic variability over the central andes. Environ. Res. Lett. 11, 094016. doi:10.1088/1748-9326/11/9/094016

Segura, H., Junquas, C., Espinoza, J. C., Vuille, M., Jauregui, Y. R., Rabatel, A., et al. (2019). New insights into the rainfall variability in the tropical andes on seasonal and interannual time scales. Clim. Dynam. 53 (1-2), 405-426. doi:10.1007/s00382-018-4590-8

Serna, L. M., Arias, P. A., and Vieira, S. C. (2018). Las corrientes superficiales de chorro del chocó y el caribe durante los eventos de El Niño y El Niño Modoki. revista de la acadamia colombiana de ciencias exactas. Físicas y Naturales 42 (165), 410-421. doi:10.18257/raccefyn.705

Shimizu, M. H., and Ambrizzi, T. (2016). MJO influence on ENSO effects in precipitation and temperature over south america. Theor. Appl. Climatol. 124, 291-301. doi:10.1007/s00704-015-1421-2

Shimizu, M. H., Ambrizzi, T., and Brant, L. (2016). Extreme precipitation events and their relationship with ENSO and MJO phases over northern south america. Int. J. Climatol. 37, 2977-2989. doi:10.1002/joc.4893

Sicart, J. E., Espinoza, J. C., Queno, L., and Medina, M. (2016). Radiative properties of clouds over a tropical bolivian glacier: seasonal variations and relationship with regional atmospheric circulation. Int. J. Climatol. 36 (8), 3116-3128. doi:10.1002/joc. 4540

Sierra, J. P., Arias, P. A., Vieira, S. C., and Agudelo, J. (2018). How well do CMIP5 models simulate the low-level jet in western colombia?. Clim. Dynam. 51 (5-6), 2247-2265. doi:10.1007/s00382-017-4010-5

Silva, Y., Takahashi, K., and Chávez, R. (2008). Dry and wet rainy seasons in the Mantaro River basin (central Peruvian Andes). Adv. Geosci. 14, 261-264. doi:10.5194/adgeo-14-261-2008

Silvestri, G., and Vera, C. (2009). Nonstationary impacts of the southern annular mode on southern hemisphere climate. J. Clim. 22 (22), 6142-6148. doi:10. 1175/2009jcli3036.1

Seiler, C., Hutjes, R. W. A., and Kabat, P. (2013). Climate variability and trends in Bolivia. J. Appl. Meteorol. Climatol. 52 (1), 130-146.

Solman, S. A., and Menéndez, C. G. (2002). ENSO-related variability of the southern hemisphere winter storm track over the eastern pacific-atlantic sector. J. Atmos. Sci. 59, 2128-2141. doi:10.1175/1520-0469(2002)059<2128: ervots $>2.0$. co;2

Sorí, R., Nieto, R., Drumond, A., Stojanovic, M., and Gimeno, L. (2019). On the connection between atmospheric moisture transport and dry conditions in rainfall climatological zones of the Niger river basin. Water 11, 622. doi:10. 3390/w11030622

Soruco, A., Vincent, C., Rabatel, A., Francou, B., Thibert, E., Sicart, J. E., et al. (2015). Contribution of glacier runoff to water resources of La Paz City, Bolivia (16S). Ann. Glaciol. 56, 147-154. doi:10.3189/2015aog70a001

Staal, A. (2018). Forest-rainfall cascades buffer against drought across the amazon. Nat. Clim. Change. 8, 539-543. doi:10.1038/s41558-018-0177-y

Stuecker, M. F. (2018). Revisiting the Pacific Meridional mode. Sci. Rep. 8, 3216 doi:10.1038/s41598-018-21537-0

Sulca, J., Takahashi, K., Espinoza, J. C., Vuille, M., and Lavado, W. (2017). Impacts of different ENSO flavors and tropical Pacific convection variability (ITCZ, SPCZ) on austral summer rainfall in south america, with a focus on peru. Int. J. Climatol. 38 (1), 420-435. doi:10.1002/joc.5185

Sulca, J., Vuille, M., Silva, Y., and Takahashi, K. (2016). Teleconnections between the Peruvian central Andes and northeast Brazil during extreme rainfall events in austral summer. J. Hydrometeorol. 17, 151026144022007. doi:10.1175/JHMD-15-0034.1

Sulca, J., Vuille, M., Roundy, P., Takahashi, K., Espinoza, J. C., Silva, Y., et al. (2018). Climatology of extreme cold events in the central Peruvian Andes during austral summer: origin, types, and teleconnections. Q. J. R. Meteorol. Soc. [Epub ahead of print]. doi:10.1002/qj.3398 
Sun, X., Renard, B., Thyer, M., Westra, S., and Lang, M. (2015). A global analysis of the asymmetric effect of ENSO on extreme precipitation. J. Hydrol. 530, 51-65. doi:10.1016/j.jhydrol.2015.09.016

Takahashi, K., and Battisti, D. (2007). Processes controlling the mean tropical pacific precipitation pattern. Part II: the SPCZ and the southeast pacific dry zone. J. Clim. 20, 5696-5706.

Takahashi, K., and Martínez, A. G. (2019). The very strong coastal El Niño in 1925 in the far-eastern Pacific. Clim. Dynam. 52, 7389-7415. doi:10.1007/s00382017-3702-1

Takahashi, K., Montecinos, A., Goubanova, K., and Dewitte, B. (2011). ENSO regimes: reinterpreting the canonical and Modoki el Niño. Geophys. Res. Lett. 38, L10704. doi:10.1029/2011GL047364

Tedeschi, R. G., Cavalcanti, I. F. A., and Grimm, A. M. (2013). Influences of two types of ENSO on South American precipitation. Int. J. Climatol. 33, 1382-1400. doi:10.1002/joc.3519

Torres-Batlló, J., Martí-Cardona, B., and Pillco-Zolá, R. (2020). Mapping evapotranspiration, vegetation and precipitation trends in the catchment of the shrinking lake poopó. Rem. Sens. 12, 73. doi:10.3390/rs12010073

Tovar Pacheco, J. A., Sayán Miranda, J. L., Verástegui, P. G., and Guzmán Martínez, A. (2006). Estado del conocimiento de la hidrogeología en perú. Bol. Geol. Min. 117 (1), 147-161.

Trachte, K., Rollenbeck, R., and Bendix, J. (2010a). Nocturnal convective cloud formation under clear-sky conditions at the eastern andes of south ecuador. J. Geophys. Res. 115, D24203. doi:10.1029/2010jd014146

Trachte, K., Nauss, T., and Bendix, J. (2010b). The impact of different terrain configurations on the formation and dynamics of katabatic flows: idealised case studies. Bound Layer Meteorol. 134, 307-325. doi:10. 1007/s10546-009-9445-8

Trachte, K., and Bendix, J. (2012). Katabatic flows and their relation to the formation of convective clouds-idealized case studies. J. Appl. Meteor. Climatol. 51 (8), 1531-1546. doi:10.1175/JAMC-D-11-0184.1

UNESCO (2006). Balance hídrico superficial del Perú a nivel multianual. Documentos Técnicos del PHI-LAC, No. 1.

Programa Hidrológico Internacional (PHI) de la Oficina Regional de Ciencia para América Latina y el Caribe de la Organización de las Naciones Unidas para la Educación, la Ciencia y la Cultura (UNESCO), Montevideo- Uruguay.

Urrea, V., Ochoa, A., and Mesa, O. (2019). Seasonality of rainfall in Colombia. Water Resour. Res. 55, 4149-4162. doi:10.1029/2018WR023316

Vallejo-Bernal, S. M., Urrea, V., Bedoya-Soto, J. M., Posada, D., Olarte, A., Cárdenas-Posso, Y., et al. (2020). Ground validation of TRMM 3B43 precipitation data over colombia monthly and seasonal timescales. Int. J. Climatol. 1-24. doi:10.1002/joc.6640

Velásquez-Restrepo, M., and Poveda, G. (2019). Estimation of the water balance of the colombian pacific region. Dyna. 86 (208), 297-306. doi:10.15446/dyna. v86n208.73587

Vera, C. (2006). Toward a unified view of the american monsoon systems. J. Clim. 19, 4977-5000. doi:10.1175/jcli3896.1

Viale, M., Bianchi, E. L. J., Cara, L., and Ruiz. (2019). Contrasting climates at both sides of the Andes in Argentina and Chile. Front. Environ. Sci. doi:10.3389/ fenvs.2019.00069

Viale, M., and Garreaud, R. (2015). Orographic effects of the subtropical and extratropical Andes on upwind precipitating clouds. J. Geophys. Res. Atmos. 120, 4962-4974. doi:10.1002/2014jd023014
Viale, M., Houze, R. A., Jr., and Rasmussen, K. L. (2013). Upstream orographic enhancement of a narrow coldfrontal rainband approaching the andes. Mon. Weather Rev. 141, 1708-1730. doi:10.1175/mwr-d-12-00138.1

Viale, M., and Nuñez, M. (2011). Climatology of winter orographic precipitation over the subtropical central andes and associated synoptic and regional characteristics. J. Hydrometeorol. 12 (4), 481-507. doi:10.1175/ 2010jhm1284.1

Vuille, M., Bradley, R., and Keimig, F. (1999). Climate variability in the andes of ecuador and its relation to tropical pacific and atlantic sea surface temperature anomalies. J. Clim. 13 (14), 2520-2535.

Vuille, M., Francou, B., Wagnon, P., Juen, I., Kaser, G., Mark, B. G., et al. (2008). Climate change and tropical andean glaciers: past, present and future. Earth Sci. Rev. 89 (3-4), 79-96. doi:10.1016/j.earscirev.2008.04.002

Vuille, M., Carey, M., Huggel, C., Buytaert, W., Rabatel, A., Jacobsen, D., et al. (2018). Rapid decline of snow and ice in the tropical andes-impacts, uncertainties and challenges ahead. Earth. Rev. 176, 195-213. doi:10.1016/j. earscirev.2017.09.019

Vuille, M., and Keimig, F. (2004). Interannual variability of summertime convective cloudiness and precipitation in the central andes derived from ISCCP-B3 data. J. Clim. 17, 3334-3348. doi:10.1175/1520-0442(2004) 017<3334:ivoscc >2.0.co;2

Wang, H., and Fu, R. (2002). Cross-equatorial flow and seasonal cycle of precipitation over south america. J. Clim. 15, 1591-1608. doi:10.1175/15200442(2002)015<1591:cefasc >2.0.co;2

Zalazar, L., Ferri Hidalgo, L., Castro, M., Gargantini, H., Gimenez, M., Pitte, P., et al. (2017). Glaciares de argentina: resultados preliminares del inventario nacional de glaciares glaciers of argentina: preliminary results of the national inventory of glaciers. Revista de Glaciares y Ecosistemas de Montañas 2, 13-22. doi:10.36580/rgem.i2.13-22

Zemp, D. C., Schleussner, C.-F., Barbosa, H. M. J., van der Ent, R. J., Donges, J. F., Heinke, J., et al. (2014). On the importance of cascading moisture recycling in south america. Atmos. Chem. Phys. 14, 13337-13359. doi:10.5194/acp-14-13337-2014

Zemp, D. C., Schleussner, C. F., Barbosa, H. M., Hirota, M., Montade, V., Sampaio, G., et al. (2017). Self-amplified Amazon forest loss due to vegetationatmosphere feedbacks. Nat. Commun. 8, 14681. doi:10.1038/ncomms14681

Ziegler, C. L., and Rasmussen, E. N. (1998). The initiation of moist convection at the dryline: forecasting issues from a case study perspective. Weather Forecast. 13, 1106-1131.

Zipser, E. J., Liu, C. T., Cecil, D. J., Nesbitt, S. W., and Yorty, D. P. (2006). Where are the most intense thunderstorms on Earth? Bull. Am. Meteorol. Soc. 87, 1057-1071. doi:10.1175/BAMS-87-8-1057

Conflict of Interest: The authors declare that the research was conducted in the absence of any commercial or financial relationships that could be construed as a potential conflict of interest.

Copyright (c) 2021 Arias, Garreaud, Poveda, Espinoza, Molina-Carpio, Masiokas, Viale, Scaff and van Oevelen. This is an open-access article distributed under the terms of the Creative Commons Attribution License (CC BY). The use, distribution or reproduction in other forums is permitted, provided the original author(s) and the copyright owner(s) are credited and that the original publication in this journal is cited, in accordance with accepted academic practice. No use, distribution or reproduction is permitted which does not comply with these terms. 